NASA/TM-2007-213635

(245)

Reexamination of Ball-Race Conformity Effects on Ball Bearing Life

Erwin V. Zaretsky

Glenn Research Center, Cleveland, Ohio

Joseph V. Poplawski

J.V. Poplawski \& Associates, Bethlehem, Pennsylvania

Lawrence E. Root

Lawrence E. Root, P.E., Lebanon, New Hampshire 


\section{NASA STI Program . . . in Profile}

Since its founding, NASA has been dedicated to the advancement of aeronautics and space science. The NASA Scientific and Technical Information (STI) program plays a key part in helping NASA maintain this important role.

The NASA STI Program operates under the auspices of the Agency Chief Information Officer. It collects, organizes, provides for archiving, and disseminates NASA's STI. The NASA STI program provides access to the NASA Aeronautics and Space Database and its public interface, the NASA Technical Reports Server, thus providing one of the largest collections of aeronautical and space science STI in the world. Results are published in both non-NASA channels and by NASA in the NASA STI Report Series, which includes the following report types:

- TECHNICAL PUBLICATION. Reports of completed research or a major significant phase of research that present the results of NASA programs and include extensive data or theoretical analysis. Includes compilations of significant scientific and technical data and information deemed to be of continuing reference value. NASA counterpart of peer-reviewed formal professional papers but has less stringent limitations on manuscript length and extent of graphic presentations.

- TECHNICAL MEMORANDUM. Scientific and technical findings that are preliminary or of specialized interest, e.g., quick release reports, working papers, and bibliographies that contain minimal annotation. Does not contain extensive analysis.

- CONTRACTOR REPORT. Scientific and technical findings by NASA-sponsored contractors and grantees.
- CONFERENCE PUBLICATION. Collected papers from scientific and technical conferences, symposia, seminars, or other meetings sponsored or cosponsored by NASA.

- SPECIAL PUBLICATION. Scientific, technical, or historical information from NASA programs, projects, and missions, often concerned with subjects having substantial public interest.

- TECHNICAL TRANSLATION. Englishlanguage translations of foreign scientific and technical material pertinent to NASA's mission.

Specialized services also include creating custom thesauri, building customized databases, organizing and publishing research results.

For more information about the NASA STI program, see the following:

- Access the NASA STI program home page at http://www.sti.nasa.gov

- E-mail your question via the Internet to help@sti.nasa.gov

- Fax your question to the NASA STI Help Desk at 301-621-0134

- Telephone the NASA STI Help Desk at 301-621-0390

- Write to: NASA Center for AeroSpace Information (CASI) 7115 Standard Drive Hanover, MD 21076-1320 
NASA/TM-2007-213635

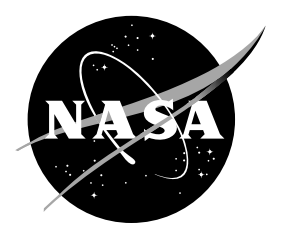

\section{Reexamination of Ball-Race Conformity Effects on Ball Bearing Life}

Erwin V. Zaretsky

Glenn Research Center, Cleveland, Ohio

Joseph V. Poplawski

J.V. Poplawski \& Associates, Bethlehem, Pennsylvania

Lawrence E. Root

Lawrence E. Root, P.E., Lebanon, New Hampshire

National Aeronautics and

Space Administration

Glenn Research Center

Cleveland, Ohio 44135 
Level of Review: This material has been technically reviewed by technical management.

Available from

NASA Center for Aerospace Information

7115 Standard Drive

Hanover, MD 21076-1320
National Technical Information Service 5285 Port Royal Road Springfield, VA 22161

Available electronically at http://gltrs.grc.nasa.gov 


\title{
Reexamination of Ball-Race Conformity Effects on Ball Bearing Life
}

\author{
Erwin V. Zaretsky \\ National Aeronautics and Space Administration \\ Glenn Research Center \\ Cleveland, Ohio 44135 \\ Joseph V. Poplawski \\ J.V. Poplawski \& Associates \\ Bethlehem, Pennsylvania 18018 \\ Lawrence E. Root \\ Lawrence E. Root, P.E. \\ Lebanon, New Hampshire 03766
}

\begin{abstract}
G. Lundberg and A. Palmgren in 1947 established the primary relation between rolling-element bearing geometry and bearing life. Their analysis of ball and roller bearings did not consider the life of the bearing's set of rolling elements independent of race life. The analysis in this report considers the life of the ball set as well as the respective lives of the races to reassess the effect of ball-race conformity on ball bearing life. The related changes in ball bearing life are incorporated in life factors that can be used to modify the bearing predicted life using the Lundberg-Palmgren equations and the ANSI/ABMA and ISO Standards. Two simple algebraic relationships were established to calculate life factors $\boldsymbol{L F}_{\boldsymbol{c}}$ to determine the effect of inner- and outer-race conformity combinations on bearing $\boldsymbol{L}_{\mathbf{1 0}}$ life for deep-groove and angular-contact ball bearings, respectively. Depending on the bearing type and series as well as conformity combinations, the calculated life for deep-groove ball bearings can be over 40 percent less than that calculated by the Lundberg-Palmgren equations. For angular-contact ball bearings, the life can vary between +16 and -39 percent from that calculated by the Lundberg-Palmgren equations. Comparing the two ball bearing types, the life factors $\boldsymbol{L} \boldsymbol{F}_{c}$ for the deep-groove bearings can be as much as 40 percent lower than that for angular-contact ball bearings. The use of a fatigue limit from either the program ASMELIFE or the proposed ISO 281:2006 standard can significantly overpredict bearing life over a range of normal operating Hertz stresses, which can result in the selection of undersized bearings for a particular application.
\end{abstract}

\section{Nomenclature}

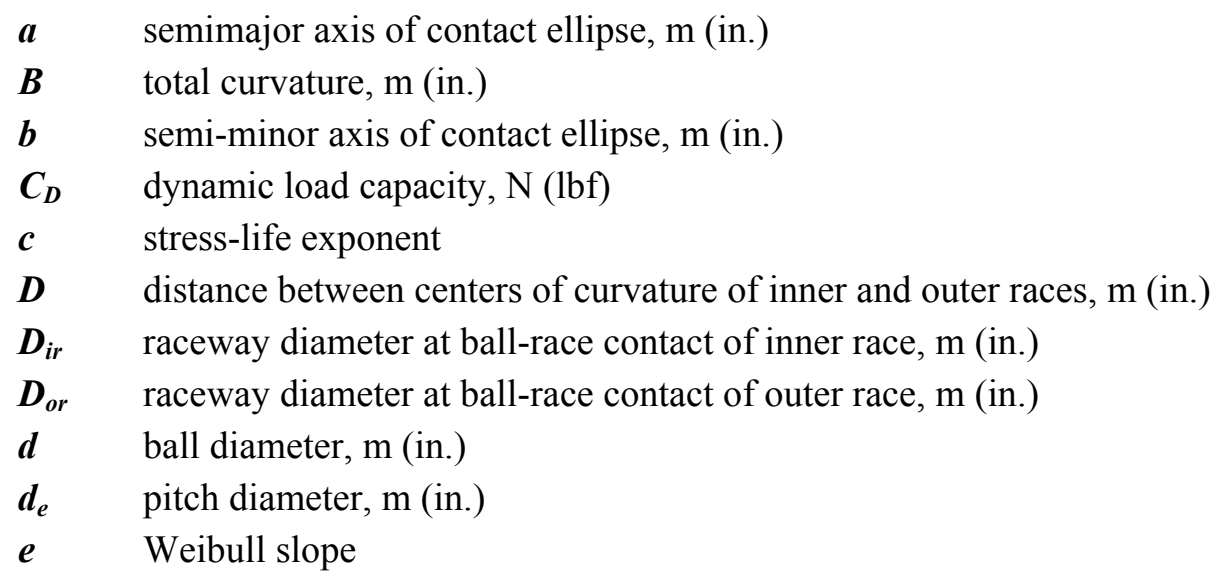




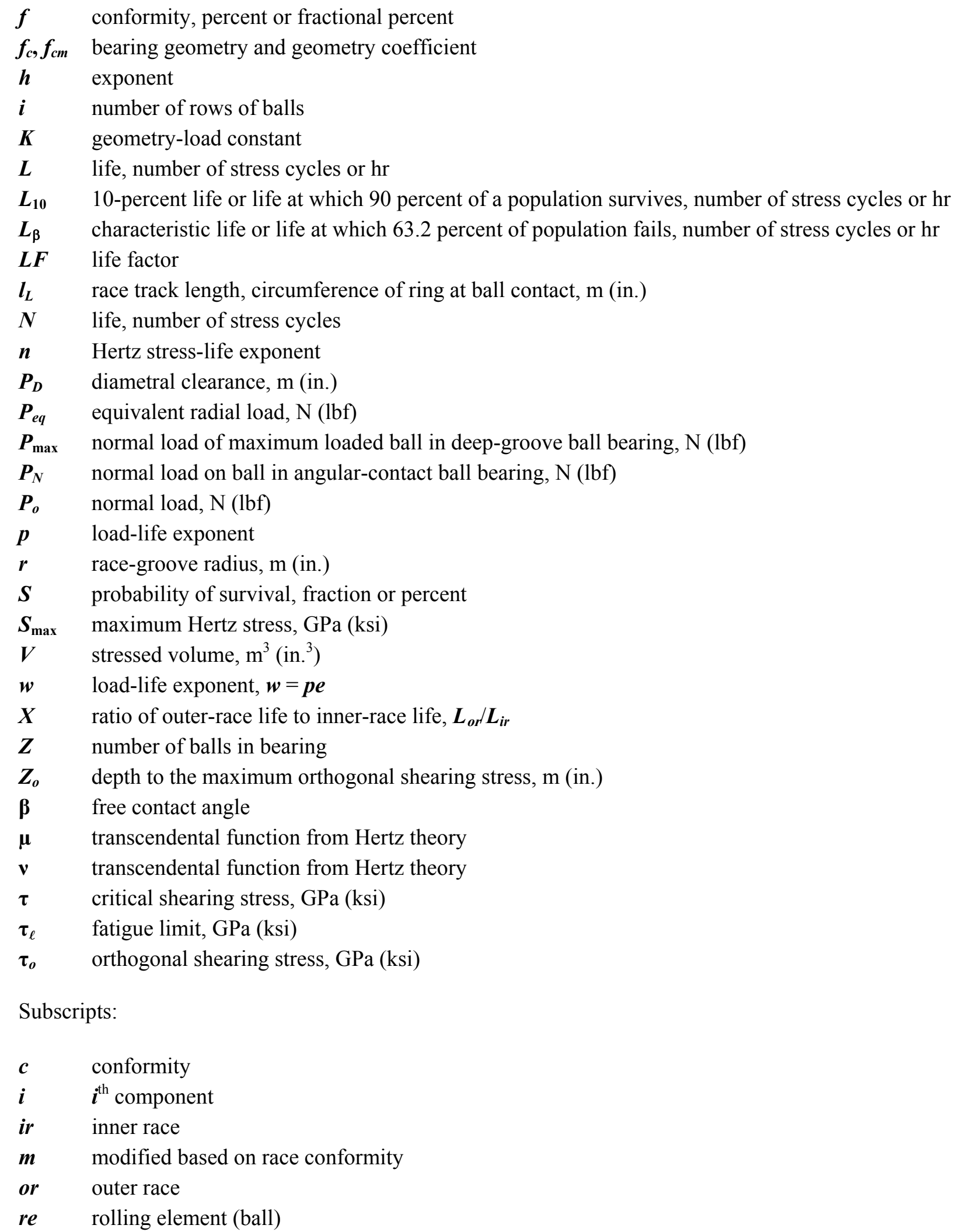




\section{Introduction}

By the close of the 19th Century, the bearing industry began to focus on sizing of bearings for specific applications and determining bearing life and reliability. In 1896, R. Stribeck (ref. 1) in Germany began fatigue testing full-scale bearings. J. Goodman (ref. 2) in 1912 in Great Britain published formulae based on fatigue data that would compute safe loads on ball and cylindrical roller bearings. In 1914, the "American Machinists Handbook and Dictionary of Shop Terms" (ref. 3), devoted 6 pages to rollingelement bearings that discussed bearing sizes and dimensions and recommended (maximum) loading at specified speeds. However, the publication (ref. 3) did not address the issue of bearing life. During this time, it would appear that rolling-element bearing fatigue testing was the only way to determine or predict the minimum or average life of ball and roller bearings.

In 1924, A. Palmgren (ref. 4) in Sweden published a paper in German outlining his approach to bearing life prediction and an empirical formula based upon the concept of an $\boldsymbol{L}_{\mathbf{1 0}}$ life or the time that 90 percent of a bearing population would equal or exceed without failure. During the next 20 years he empirically refined his approach to bearing life prediction and matched his predictions to test data (ref. 5). However, his formula lacked a theoretical basis or an analytical proof.

In 1939, W. Weibull (refs. 6 and 7) in Sweden published his theory of failure. Weibull was a contemporary of Palmgren and shared the results of his work with him. Palmgren in concert with G. Lundberg, also of Sweden, in 1947 incorporated his previous work along with that of Weibull and what appears to be the work of V. Thomas and H. Hoersch (ref. 8) into what has become known as the Lundberg-Palmgren theory (refs. 9 and 10). (In 1930, V. Thomas and H. Hoersch (ref. 8) at the University of Illinois, Urbana, developed an analysis for determining subsurface principal stresses under Hertzian contact (ref. 11). Lundberg and Palmgren (refs. 9 and 10) do not reference the work of V. Thomas and H. Hoersch (ref. 8 in their papers.)

Lundberg and Palmgren (refs. 9 and 10) established the primary relation between bearing geometry and bearing life. For ball bearings they related bearing life to five variables. These are ball diameter, pitch diameter, inner- and outer-race conformities, number of balls, and contact angle. Except for bearing contact angle, the relation between these parameters remains the same regardless of whether the bearing is a deep-groove ball bearing or an angular-contact ball bearing. These relations have been incorporated into both the International Organization for Standardization (ISO) and the American National Standards Institute (ANSI)/American Bearing Manufactures Association (ABMA) standards (ABMA was formerly AFBMA, Anti-Friction Bearing Manufacturers Association) for the load ratings and life of rollingelement bearings (refs. 12 to 14) as well as in current bearing codes to predict life.

The Lundberg-Palmgren equations only relate to the lives of the inner and outer races and incorporate ball life into their analysis by inference (ref. 9). It has since been recognized (ref. 15) that the life of the ball set in relation to the races is different for a deep-groove ball bearing and an angular-contact ball bearing as well as being dependent on the relative contact (Hertz) stresses at the inner and outer races. It is the objectives of the work reported herein to (a) consider the life of the ball set as well as the lives of the respective races to reassess the effect of ball-race conformities on ball bearing life and (b) incorporate the related changes in ball bearing life to life factors that can be used to modify the bearing predicted life using the Lundberg-Palmgren equations and the ANSI/ABMA and the ISO Standards.

\section{Ball Bearing Geometry and Stresses}

\section{Bearing Geometry}

While there are several types of ball bearings, there are two common basic types. These are the deepgroove ball bearing (figs. 1 and 2(a)) that is designed to handle primarily radial loads and the angularcontact ball bearing (fig. 2(b)) designed to handle primarily thrust loads. These bearings comprise a plurality of balls interspersed between an inner and outer race and separated and positioned by a cage or separator. 


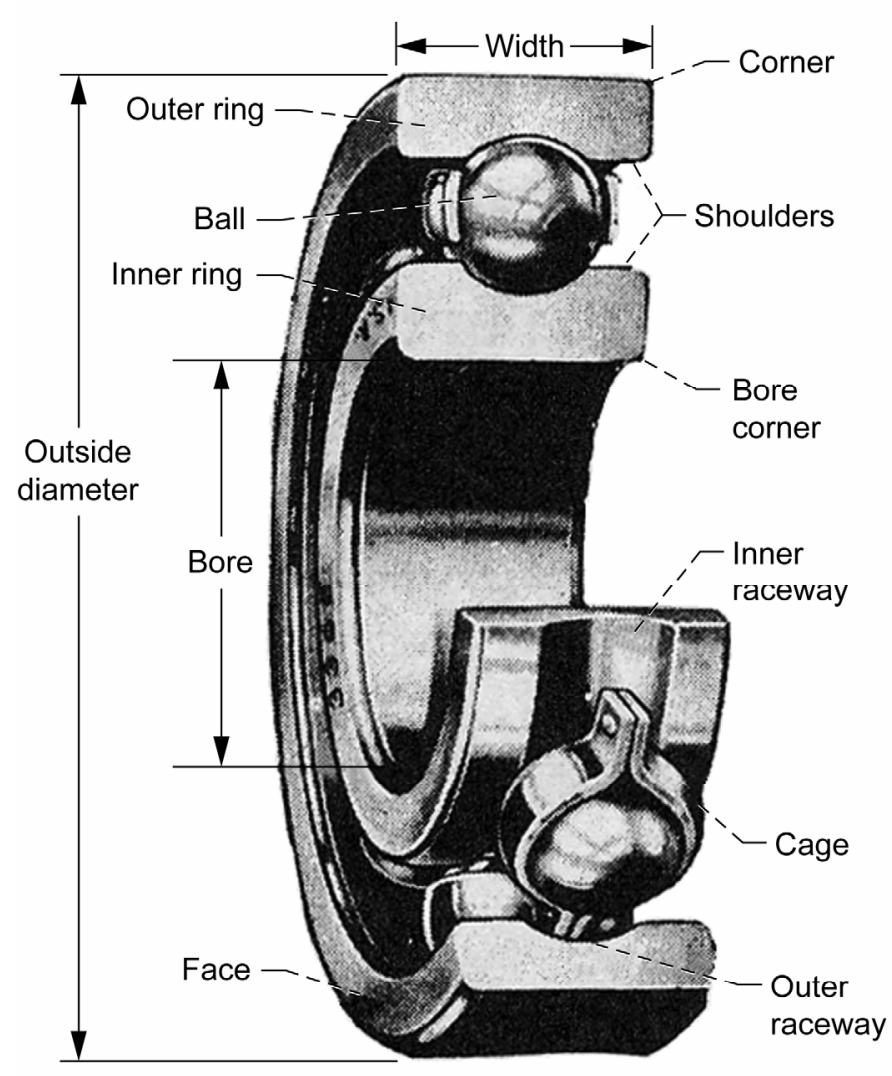

(a)

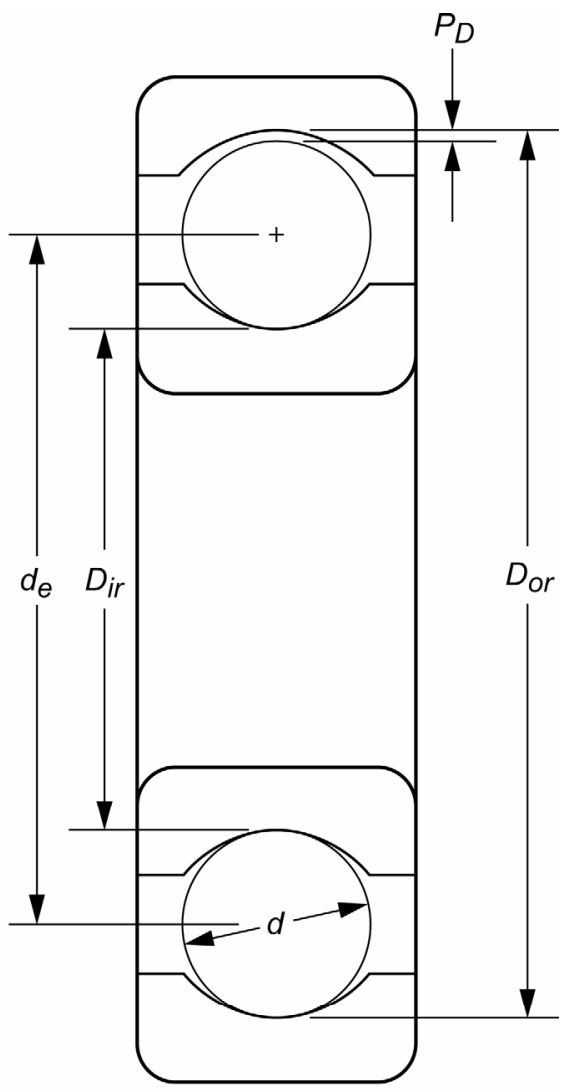

(b)

Figure 1.-Deep-groove ball bearing. (a) Schematic. (b) Cross section without cage.

(a)

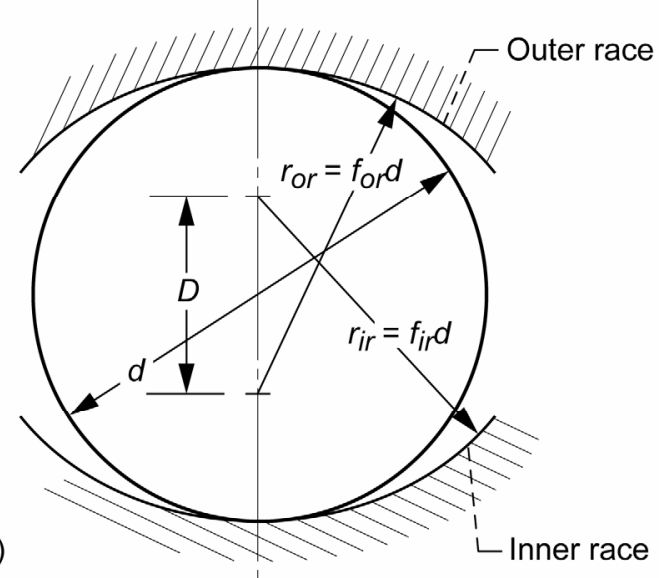

(b)

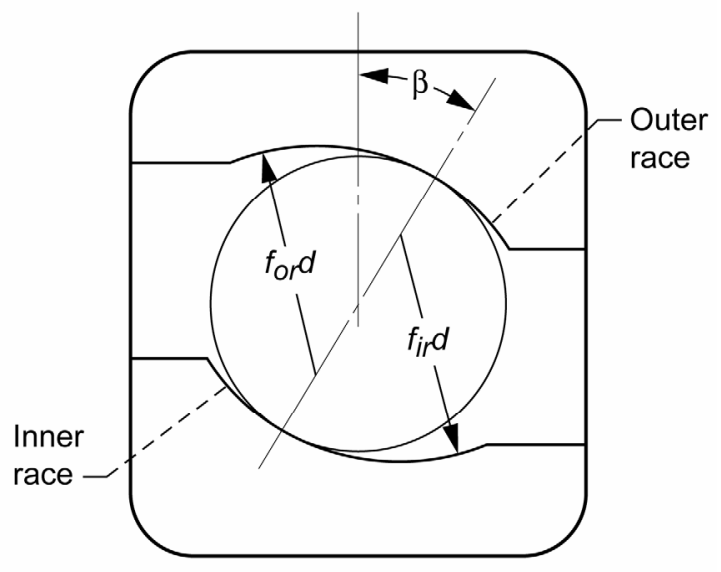

Figure 2.-Ball-race conformity. (a) Deep-groove ball bearing. (b) Angular-contact ball bearing. 
The operating characteristics of a ball bearing are dependent its internal fitup measured by the diametral clearance $\left(\boldsymbol{P}_{\boldsymbol{D}}\right)$ illustrated in the cross section schematic of figure 1(b) where

$$
P_{D}=D_{o r}-D_{i r}-2 d
$$

where $\boldsymbol{D}_{\boldsymbol{o r}}$ and $\boldsymbol{D}_{\boldsymbol{i r}}$ are the raceway diameters at the ball-race contact of the outer and inner races, respectively, and $\mathrm{d}$ is the ball diameter. While diametral clearance is generally used in conjunction with single row deep-groove ball bearings, it is applicable to angular-contact ball bearings where there is a relation between diametral clearance $\boldsymbol{P}_{D}$, race curvatures $\boldsymbol{r}_{i r}$ and $\boldsymbol{r}_{\boldsymbol{o r}}$, and free contact angle $\boldsymbol{\beta}$ (ref. 16) (fig. 2(b)).

Where $\boldsymbol{P}_{D}=0$, the bearing pitch diameter is

$$
\boldsymbol{d}_{\boldsymbol{e}}=\frac{\boldsymbol{D}_{\boldsymbol{o r}}+\boldsymbol{D}_{\boldsymbol{i r}}}{2}
$$

Referring to figure 2, the race conformity $\boldsymbol{f}$ is the ratio of the race-groove radius, or curvature, $\boldsymbol{r}$ to the ball diameter $\boldsymbol{d}$ in a plane passing through the bearing axis and transverse to the raceway and expressed as a percent or fractional percent (ref. 16) where

$$
f=\frac{r}{d}
$$

The race-groove radius, or curvature, can be expressed as

$$
\boldsymbol{r}=\boldsymbol{f d}
$$

The distance between the centers of curvatures of two races in line contact with a ball is indicated by $\boldsymbol{D}$ in figure 2(a). It is a fixed quantity depending on race radii and ball diameter where

$$
D=\left(\boldsymbol{f}_{\text {or }}+\boldsymbol{f}_{\text {ir }}-1\right) \boldsymbol{d}
$$

If we let

$$
\boldsymbol{B}=\left(\boldsymbol{f}_{\text {or }}+\boldsymbol{f}_{\text {ir }}-1\right)
$$

Then

$$
\boldsymbol{D}=\boldsymbol{B d}
$$

The quantity $\boldsymbol{B}$ is referred to as the "total curvature" and is a measure of the conformity of the inner and outer races (ref. 16). The computation of deflection in ball bearings under load is dependent on the value of the total curvature $\boldsymbol{B}$ (ref. 16).

Figure 2(b) is a schematic of a cross section of a ball in an angular-contact ball bearing showing a free contact angle $\boldsymbol{\beta}$. The free contact angle is the contact angle of the bearing without load being applied. It is defined as "the angle made by a line passing through the points of contact of the ball and both raceways with a plane perpendicular to the axis of the bearing when both races are centered to each other and one race is axially displaced with respect to the other without the application of measurable force (ref. 16)." The free contact angle is determined by the diametral clearance, $\boldsymbol{P}_{\boldsymbol{D}}$, and the total curvature $\boldsymbol{B}$, where

$$
\cos \boldsymbol{\beta}=\frac{2 \boldsymbol{B d}-\boldsymbol{P}_{\boldsymbol{D}}}{2 \boldsymbol{B d}}
$$

or

$$
\boldsymbol{P}_{\boldsymbol{D}}=2 \boldsymbol{B} \boldsymbol{d}(1-\cos \boldsymbol{\beta})
$$




\section{Contact (Hertz) Stress}

The contact (Hertz) stresses at the respective races of a bearing are a function of the bearing geometry, the normal load at the contact and the elastic properties of the bearing materials. Jones (ref. 16) relates the Hertz contact theory for the stresses of nonconforming bodies in contact for both ball and roller bearings. From Jones (ref. 16), the following relations for the maximum Hertz stresses $\boldsymbol{S}_{\max }$ at the inner and outer races of ball bearings can be derived:

For deep-groove ball bearings with a radial load only,

$$
\boldsymbol{S}_{\text {max }_{o r}}=\frac{K\left[-\frac{2}{D_{o r}}+\frac{4}{d}-\frac{1}{f_{o r} d}\right]^{2 / 3} P_{\max }^{1 / 3}}{\mu \nu}
$$

for the outer race, and

$$
S_{\max _{i r}}=\frac{K\left[\frac{2}{D_{i r}}+\frac{4}{d}-\frac{1}{f_{i r} d}\right]^{2 / 3} P_{\max }^{1 / 3}}{\mu \nu}
$$

for the inner race.

For angular-contact ball bearings with a thrust load only,

$$
\boldsymbol{S}_{\text {max }_{\boldsymbol{o r}}}=\frac{\boldsymbol{K}\left[-\frac{2 \cos \beta}{\boldsymbol{d}_{\boldsymbol{e}}+\boldsymbol{d} \cos \beta}+\frac{4}{\boldsymbol{d}}-\frac{1}{\boldsymbol{f}_{\text {or }} \boldsymbol{d}}\right]^{2 / 3} \boldsymbol{P}_{N}^{1 / 3}}{\mu \nu}
$$

for the outer race and

$$
S_{\text {max }_{i r}}=\frac{K\left[\frac{2 \cos \beta}{d_{e}-\boldsymbol{d c o s} \beta}+\frac{4}{d}-\frac{1}{f_{i r} \boldsymbol{d}}\right]^{2 / 3} \boldsymbol{P}_{N}^{1 / 3}}{\mu \nu}
$$

for the inner race.

For bearing steel on bearing steel, $\boldsymbol{K}=1.58 \times 10^{-3}$ for $\boldsymbol{S}_{\max }$ in GPa and $\boldsymbol{K}=23.58$ for $\boldsymbol{S}_{\max }$ in ksi. The values for the transcendental functions, $\boldsymbol{\mu}$ and $\mathbf{v}$, vary with conformity $\boldsymbol{f}$ and can be found in reference 16 .

From the above equations, the conformities at the inner and outer races affect the resultant Hertz stresses and the lives of their respective raceways. The determination of life factors $\boldsymbol{L} \boldsymbol{F}_{\boldsymbol{i r}}$ and $\boldsymbol{L} \boldsymbol{F}_{\boldsymbol{o r}}$ based on conformities for the inner and outer races, respectively, can be calculated by normalizing the equations for Hertz stress for the inner and outer races to a conformity of 0.52 (the value of 0.52 was chosen as a typical reference value). The change in stress for the same race diameter but varying the conformity is determined as a function of conformity. The accepted relation between life $\boldsymbol{L}$ and $\boldsymbol{S}_{\max }$ is

$$
\boldsymbol{L} \sim\left(\frac{1}{\boldsymbol{S}_{\max }}\right)^{\boldsymbol{n}}
$$


Where $\mathrm{n}$ is normally accepted as being 9 (ref. 9). From equation (8a) for the same normal load $\boldsymbol{P}_{\boldsymbol{o}}$, the ratio of the stress at a 0.52 conformity to that of the ball-race conformity gives the appropriate life factor where

$$
\boldsymbol{L} \boldsymbol{F}=\left(\frac{\boldsymbol{S}_{\max _{0.52}}}{\boldsymbol{S}_{\max }}\right)^{9}
$$

Representative values of these life factors for conformities ranging from 0.505 to 0.57 are given for inner and outer races, respectively, in table I. It was found, subject to round-off error, that the life factors based upon conformities for the respective inner and outer races were independent of bearing size and series. However, they were different at the inner and outer races for each respective conformity.

TABLE I.-REPRESENTATIVE LIFE FACTORS FOR INNER AND OUTER RACE BASED ON BALL-RACE CONFORMITY

\begin{tabular}{|c|c|c|c|c|c|c|c|c|c|c|c|c|c|}
\hline \multicolumn{14}{|c|}{$\begin{array}{l}\text { Ball-race conformity, } \\
\boldsymbol{f}\end{array}$} \\
\hline 0.505 & 0.51 & 0.515 & 0.52 & 0.525 & 0.53 & 0.535 & 0.54 & 0.545 & 0.55 & 0.556 & 0.56 & 0.565 & 0.57 \\
\hline \multicolumn{14}{|c|}{$\begin{array}{l}\text { Inner-race life factors, } \\
\boldsymbol{L F}_{\boldsymbol{i r}}\end{array}$} \\
\hline 4.5 & 2.04 & 1.22 & 1 & 0.62 & 0.49 & 0.40 & 0.33 & 0.29 & 0.25 & 0.22 & 0.19 & 0.17 & 0.16 \\
\hline \multicolumn{14}{|c|}{$\begin{array}{l}\text { Outer-race life factors, } \\
\qquad \boldsymbol{L F}_{\boldsymbol{o r}}\end{array}$} \\
\hline 5.4 & 2.5 & 1.3 & 1 & 0.75 & 0.61 & 0.47 & 0.38 & 0.32 & 0.28 & 0.24 & 0.21 & 0.19 & 0.17 \\
\hline
\end{tabular}

\section{Bearing Life Analysis}

In probabilistic life models the bearing physical characteristics, applied load, operating profile, and environment determine the probability of failure, assuming that the life is represented by a known probability function. Weibull (refs. 6 and 7) was the first to suggest a reasonable way to estimate material fracture strength with such a probability function. Based upon the work of Weibull, G. Lundberg and A. Palmgren (ref. 9) in 1947 showed that the probability of survival $\boldsymbol{S}$ could be expressed as a power function of the orthogonal shearing stress $\tau_{\boldsymbol{o}}$, life $N$, depth to the maximum orthogonal shear stress $\boldsymbol{Z}_{\boldsymbol{o}}$, and stressed volume $\boldsymbol{V}$ of the race. That is

$$
\ln \frac{1}{S} \sim \tau_{o}^{c} \frac{N^{e}}{Z_{o}^{h}} V
$$

From equation (1) and for a given value of $\boldsymbol{S}$, the life $\boldsymbol{L}$ is

$$
L=N \sim\left(\frac{1}{\tau_{o}}\right)^{c / e}\left(\frac{1}{V}\right)^{1 / e}\left(Z_{o}\right)^{h / e}
$$

where for ball bearings the stressed volume of the race

$$
V=a l_{L} Z_{o}
$$




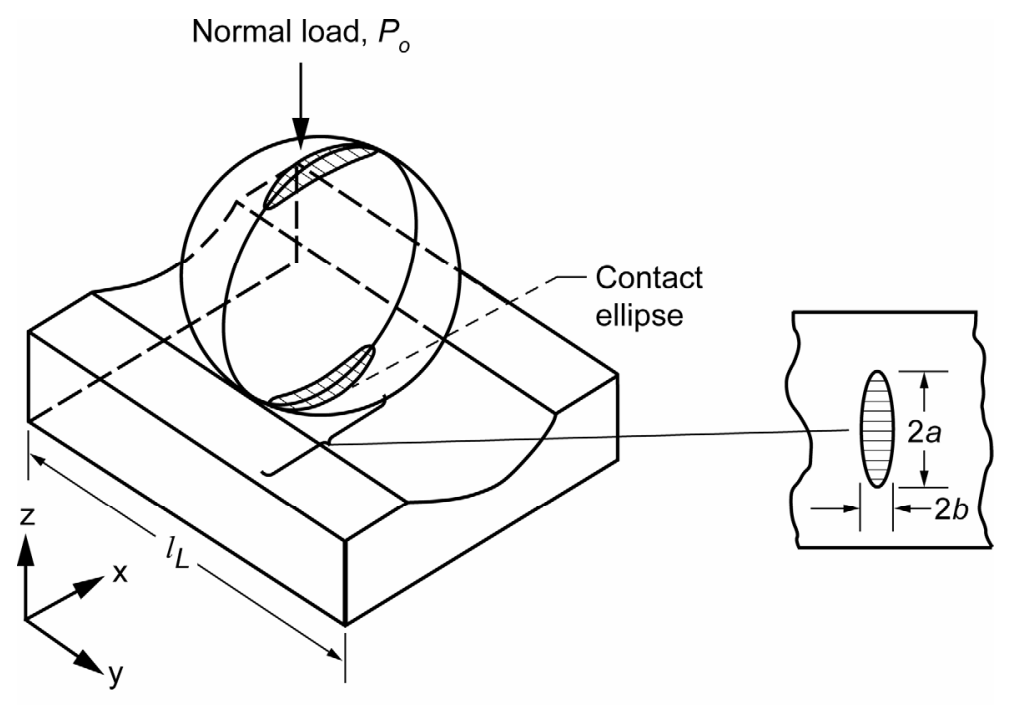

Figure 3.-Schematic of contact profile of ball on raceway.

where $\boldsymbol{a}$ is the semimajor axis of the contact ellipse and $\boldsymbol{l}_{\boldsymbol{L}}$ is the race track length or circumference of the ring at ball contact. The resultant variables in equations (9) and (11) are also shown in figure 3.

Lundberg and Palmgren (ref. 9) incorporated into their analysis a method and distribution function developed by Weibull (refs. 6 and 7) for statistically describing the fatigue life of materials, referred to as the two-parameter Weibull distribution function:

$$
\ln \ln \frac{1}{\boldsymbol{S}}=\boldsymbol{e} \ln \left(\frac{\boldsymbol{L}}{\boldsymbol{L}_{\boldsymbol{\beta}}}\right) \text { where } 0<\boldsymbol{L}<\infty \text { and } 0<\boldsymbol{S}<1
$$

From equation (12), Lundberg and Palmgren (ref. 9) first derived the relationship between individual component life and system life. A bearing is a system of multiple components, each with a different life. As a result, the life of the system is different from the life of an individual component in the system. The $\boldsymbol{L}_{\mathbf{1 0}}$ bearing system life, where 90 percent of the population survives, can be expressed as

$$
\frac{1}{L_{10}^{e}}=\frac{1}{L_{10 i r}^{e}}+\frac{1}{L_{10 o r}^{e}}
$$

where the life of the rolling elements, by inference, is incorporated into the life of each raceway tacitly assuming that all components have the same Weibull slope $\boldsymbol{e}$. In properly designed and operated rollingelement bearings, fatigue of the cage or separator should not occur and, therefore, is not considered in determining bearing life and reliability. From equations (12) and (13), Lundberg and Palmgren (ref. 9) derived the following relation:

$$
L_{10}=\left(\frac{C_{D}}{P_{e q}}\right)^{p}
$$

From Lundberg-Palmgren (ref. 9), the load-life exponent $\boldsymbol{p}$ equals 3 for ball bearings. 
Formulas for the basic load capacity for ball bearings that derived from Lundberg and Palmgren (ref. 9) and incorporated into the ANSI/ABMA Standards (refs. 13 and 14) and the ISO Standards (ref. 12) are as follows:

For ball bearings with $\boldsymbol{d} \leq 25 \mathrm{~mm}$ and $\boldsymbol{\beta} \leq 45^{\circ}$,

$$
C_{D}=\boldsymbol{f}_{c m}(\boldsymbol{i} \cos \beta)^{0.7} \boldsymbol{Z}^{2 / 3} \boldsymbol{d}^{1.8}
$$

For ball bearings with $\boldsymbol{d}>25 \mathrm{~mm}$ and $\boldsymbol{\beta} \leq 45^{\circ}$,

$$
C_{D}=f_{c m}(i \cos \beta)^{0.7} Z^{2 / 3} d^{1.4}
$$

where $\boldsymbol{f}_{c m}$ is the bearing geometry and material coefficient. Prior to 1990 , the coefficient $\boldsymbol{f}_{c m}$ was designated as $f_{c}$ (ref. 15). The bearing geometry including the race conformities is incorporated into this coefficient.

While Lundberg and Palmgren allow for calculating the effect of ball bearing race conformities into their life calculation, the standards and the bearing manufacturers' catalogs generally normalize their values of $\boldsymbol{f}_{c m}$ to conformities on the inner and outer races of 0.52 (52 percent). Representative values of $\boldsymbol{f}_{\mathrm{cm}}$ as a function of the year introduced by ANSI/ABMA are given in table II for representative bearing sizes, indicated by values of $\frac{d \cos \beta}{d_{e}}$. For values of $\frac{d \cos \beta}{d_{e}}$ not shown in table II, values of $\boldsymbol{f}_{c m}$ are obtained by interpolating between the respective values shown. These coefficients apply to both deep-groove and angular-contact ball bearings without distinction. Their relative sizes and relative dynamic load capacities $C_{D}$ are illustrated in figure 4 for the five series of 40-mm-bore deep-groove ball bearings.

In ANSI/ABMA standards 12.1 and 12.2 (refs. 17 and 18) for instrument bearings, the bearing geometry and material coefficient $\boldsymbol{f}_{c m}$ contain the representative combinations of inner- and outer-race conformities. The values of the coefficient $\boldsymbol{f}_{c m}$ are summarized in table III. Again, the standards do not distinguish between deep-groove (radially-loaded) and angular-contact (thrust-loaded) ball bearings nor do they separate the effect of ball life from that of the raceway.

TABLE II.-REPRESENTATIVE VALUES OF ROLLING-ELEMENT BEARING GEOMETRY AND MATERIAL COEFFICIENT $\boldsymbol{f}_{\boldsymbol{c} \boldsymbol{m}}$ IN ANSI/ABMA STANDARD 9 (REFS. 13 AND 14) FOR REPRESENTATIVE BALL BEARING SIZES BY YEAR INTRODUCED

\begin{tabular}{|c|c|c|c|c|c|}
\hline \multirow{2}{*}{$\begin{array}{c}\text { Bearing size, } \\
\frac{d \cos \beta}{d_{e}}\end{array}$} & \multicolumn{5}{|c|}{$\begin{array}{l}\text { Bearing geometry and material coefficient, } \\
\qquad f_{c m}{ }^{\mathrm{b}}\end{array}$} \\
\hline & 1960 & 1972 & 1978 & 1990 & $\begin{array}{c}1985 \\
\text { (standards } 12.1 \text { and 12.2) }\end{array}$ \\
\hline 0.05 & $\begin{array}{l}46.75 \\
(3550)\end{array}$ & $\begin{array}{r}59.52 \\
(4520)\end{array}$ & $\begin{array}{r}46.75 \\
(3550)\end{array}$ & $\begin{array}{r}60.70 \\
(4610)\end{array}$ & $\begin{array}{c}60.70 \\
(4620)\end{array}$ \\
\hline .10 & $\begin{array}{l}55.57 \\
(4220)\end{array}$ & $\begin{array}{l}73.34 \\
(5570)\end{array}$ & $\begin{array}{l}55.57 \\
(4220)\end{array}$ & $\begin{array}{l}72.16 \\
(5480)\end{array}$ & $\begin{array}{r}72.69 \\
(5520)\end{array}$ \\
\hline .16 & $\begin{array}{l}59.65 \\
(4530)\end{array}$ & $\begin{array}{l}84.41 \\
(6410)\end{array}$ & $\begin{array}{l}59.65 \\
(4530)\end{array}$ & $\begin{array}{r}77.56 \\
(5890)\end{array}$ & $\begin{array}{r}77.56 \\
(5890)\end{array}$ \\
\hline .22 & $\begin{array}{l}59.65 \\
(4530)\end{array}$ & $\begin{array}{c}92.96 \\
(7060)\end{array}$ & $\begin{array}{c}59.65 \\
(4350)\end{array}$ & $\begin{array}{c}77.56 \\
(5890)\end{array}$ & $\begin{array}{c}79.14 \\
(6010)\end{array}$ \\
\hline .28 & $\begin{array}{c}57.15 \\
(4340)\end{array}$ & $\begin{array}{l}100.08 \\
(7600)\end{array}$ & $\begin{array}{c}57.15 \\
(4340)\end{array}$ & $\begin{array}{c}74.27 \\
(5640)\end{array}$ & $\begin{array}{c}74.40 \\
(5650)\end{array}$ \\
\hline .34 & $\begin{array}{c}53.33 \\
(4050)\end{array}$ & $\begin{array}{c}106 \\
(8050)\end{array}$ & $\begin{array}{c}53.33 \\
(4050)\end{array}$ & $\begin{array}{c}69.26 \\
(5260)\end{array}$ & $\begin{array}{c}69.26 \\
(5260)\end{array}$ \\
\hline .40 & ------- & ------ & $\begin{array}{c}75.94 \\
(3670)\end{array}$ & $\begin{array}{c}62.94 \\
(4780)\end{array}$ & - \\
\hline
\end{tabular}
[Inner- and outer-race conformities are equal to 0.52.]

${ }^{\mathrm{a}}$ Values of $\boldsymbol{f}_{\boldsymbol{c m}}$ are for use with SI units; those in parentheses are for use with English units.

${ }^{\mathrm{b}}$ Prior to $1990, \boldsymbol{f}_{c m}$ was designated as $\boldsymbol{f}_{c}$. 


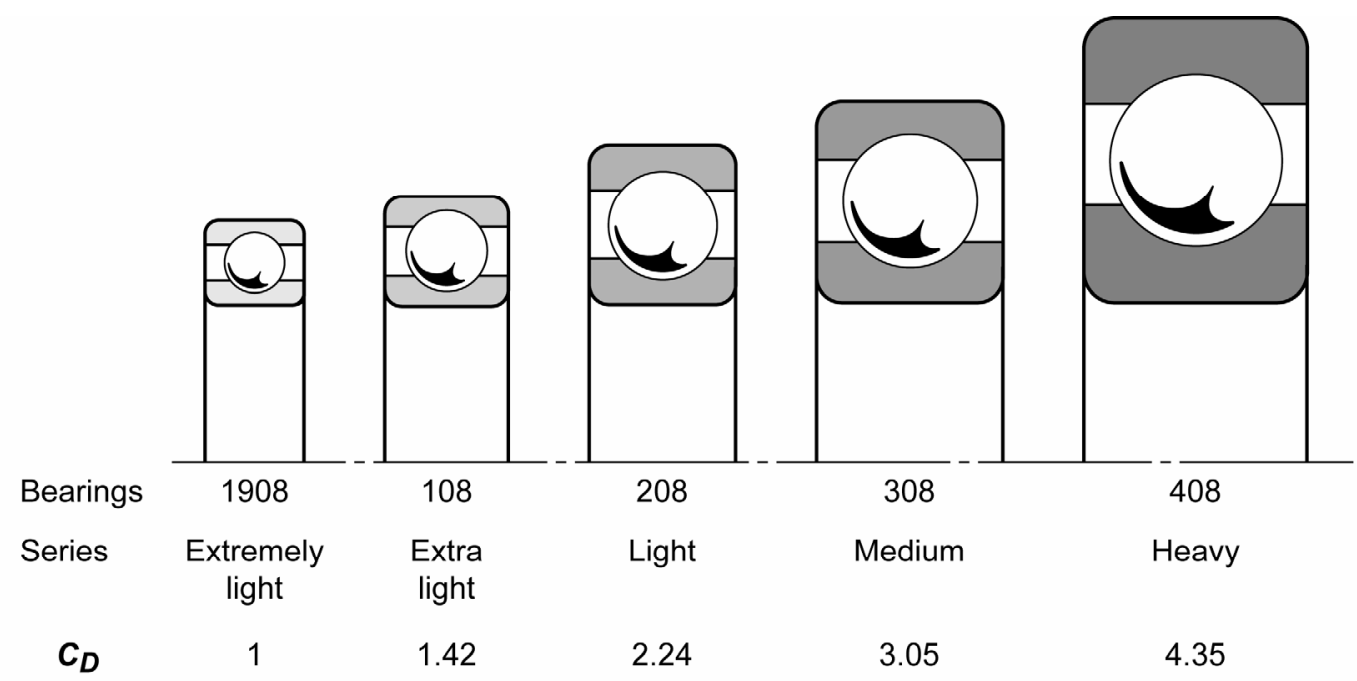

Figure 4.-Relative sizes and dynamic capacities, $C_{D}$, of $40-\mathrm{mm}$-bore deep-groove ball bearings.

TABLE III.-REPRESENTATIVE VALUES FOR ROLLING-ELEMENT BEARING GEOMETRY AND MATERIAL COEFFICIENT $\boldsymbol{f}_{\boldsymbol{c} \boldsymbol{m}}$ IN ANSI/ABMA STANDARD 12.1 AND 12.2 (REFS. 17 AND 18) FOR COMBINATIONS OF INNER- AND OUTER-RACE CONFORMITIES

\begin{tabular}{|c|c|c|c|c|c|c|c|c|c|}
\hline \multirow[t]{5}{*}{$\frac{d \cos \beta}{d_{e}}$} & \multicolumn{9}{|c|}{$\begin{array}{l}\text { Bearing geometry and material coefficient, }{ }^{\mathrm{a}} \\
\qquad \boldsymbol{f}_{\boldsymbol{c m}}{ }^{\mathrm{b}}\end{array}$} \\
\hline & \multicolumn{9}{|c|}{$\begin{array}{c}\text { Inner-race conformity, } \\
f_{i r}\end{array}$} \\
\hline & 0.515 & 0.52 & 0.52 & 0.52 & 0.53 & 0.54 & 0.54 & 0.54 & 0.57 \\
\hline & \multicolumn{9}{|c|}{$\begin{array}{l}\text { Outer-race conformity, } \\
\qquad \boldsymbol{f}_{\boldsymbol{o r}}\end{array}$} \\
\hline & 0.515 & 0.52 & 0.53 & 0.54 & 0.54 & 0.54 & 0.56 & 0.60 & 0.57 \\
\hline 0.05 & $\begin{array}{c}68.21 \\
(5180)\end{array}$ & $\begin{array}{c}60.84 \\
(4620)\end{array}$ & $\begin{array}{c}56.62 \\
(4300)\end{array}$ & $\begin{array}{c}53.33 \\
(4050)\end{array}$ & $\begin{array}{r}49.51 \\
(3760)\end{array}$ & $\begin{array}{r}46.48 \\
(3530)\end{array}$ & $\begin{array}{c}43.45 \\
(3300)\end{array}$ & $\begin{array}{l}38.98 \\
(2960)\end{array}$ & $\begin{array}{r}37.79 \\
(2870)\end{array}$ \\
\hline .10 & $\begin{array}{c}81.11 \\
(6160)\end{array}$ & $\begin{array}{r}72.63 \\
(5520)\end{array}$ & $\begin{array}{c}68.74 \\
(5220)\end{array}$ & $\begin{array}{c}65.58 \\
(4980)\end{array}$ & $\begin{array}{r}59.65 \\
(4530)\end{array}$ & $\begin{array}{r}55.30 \\
(4200)\end{array}$ & $\begin{array}{c}52.67 \\
(4000)\end{array}$ & $\begin{array}{l}48.59 \\
(3690)\end{array}$ & $\begin{array}{r}44.90 \\
(3410)\end{array}$ \\
\hline .16 & $\begin{array}{c}86.91 \\
(6600)\end{array}$ & $\begin{array}{r}77.56 \\
(5890)\end{array}$ & $\begin{array}{c}75.32 \\
(5720) \\
\end{array}$ & $\begin{array}{c}73.08 \\
(5550)\end{array}$ & $\begin{array}{r}64.92 \\
(4930) \\
\end{array}$ & $\begin{array}{r}59.39 \\
(4510)\end{array}$ & $\begin{array}{c}57.67 \\
(4380)\end{array}$ & $\begin{array}{c}55.57 \\
(4220)\end{array}$ & $\begin{array}{r}48.19 \\
(3660)\end{array}$ \\
\hline .22 & $\begin{array}{c}86.91 \\
(6600)\end{array}$ & $\begin{array}{r}79.14 \\
(6010)\end{array}$ & $\begin{array}{c}76.37 \\
(5800)\end{array}$ & $\begin{array}{r}75.06 \\
(5700)\end{array}$ & $\begin{array}{r}65.58 \\
(4980)\end{array}$ & $\begin{array}{r}59.39 \\
(4510)\end{array}$ & $\begin{array}{c}58.47 \\
(4440)\end{array}$ & $\begin{array}{c}56.62 \\
(4300)\end{array}$ & $\begin{array}{r}48.19 \\
(3660)\end{array}$ \\
\hline .28 & $\begin{array}{c}83.52 \\
(6330)\end{array}$ & $\begin{array}{r}74.40 \\
(5650)\end{array}$ & $\begin{array}{c}73.74 \\
(5600)\end{array}$ & $\begin{array}{c}73.21 \\
(5560)\end{array}$ & $\begin{array}{r}63.21 \\
(4800)\end{array}$ & $\begin{array}{r}56.88 \\
(4320)\end{array}$ & $\begin{array}{c}56.49 \\
(4290)\end{array}$ & $\begin{array}{c}55.57 \\
(4220)\end{array}$ & $\begin{array}{c}42.22 \\
(3510)\end{array}$ \\
\hline .34 & $\begin{array}{c}77.69 \\
(5900)\end{array}$ & $\begin{array}{r}69.26 \\
(5260)\end{array}$ & $\begin{array}{c}69.00 \\
(5240)\end{array}$ & $\begin{array}{c}68.74 \\
(5220)\end{array}$ & $\begin{array}{r}58.99 \\
(4480)\end{array}$ & $\begin{array}{r}52.93 \\
(4020)\end{array}$ & $\begin{array}{c}52.54 \\
(3990)\end{array}$ & $\begin{array}{l}52.41 \\
(3980)\end{array}$ & $\begin{array}{r}43.06 \\
(3270)\end{array}$ \\
\hline
\end{tabular}

${ }^{\mathrm{a}}$ Values of $\boldsymbol{f}_{c m}$ are for use with SI units; those in parentheses are for use with English units.

${ }^{\mathrm{b}}$ Prior to $1990, \boldsymbol{f}_{c m}$ was designated as $\boldsymbol{f}_{c}$.

\section{Results and Discussion}

G. Lundberg and A. Palmgren in 1947 (ref. 9) established the primary relation between bearing geometry and bearing life. For ball bearings they related bearing life to five variables. These are ball diameter, pitch diameter, inner- and outer-race conformities, number of balls, and contact angle. Except for bearing contact angle, the relation between these parameters remains the same regardless of whether the bearing is a deep-groove ball bearing or an angular-contact ball bearing. These relations have been incorporated into both the ANSI/ABMA and the ISO Standards to predict bearing life as well as current life prediction bearing codes (refs. 12,13,17, and 18). The Lundberg-Palmgren equation (ref. 9) only 
relates to the lives of the inner and outer races and incorporate ball life into their analysis by inference. It has since been recognized that the life of the ball set in relation to the races is different for a deep-groove ball bearing and an angular-contact ball bearing as well as being dependent on the relative contact (Hertz) stresses at the inner and outer races (ref. 15).

\section{Ball Set Life}

Lundberg and Palmgren (ref. 9) do not directly calculate the life of the rolling-element (ball or roller) set of the bearing. However, through benchmarking of the equations with bearing life data by use of a material-geometry factor $f_{c m}$, the life of the rolling-element set is implicitly included in the life calculation of equations (15a) and (15b).

The rationale for not including the rolling-element set in equation (13) appears in the 1945 edition of A. Palmgren's book (ref. 5) wherein he states that, "...the fatigue phenomenon which determines the life (of the bearing) usually develops on the raceway of one ring or the other. Thus, the rolling elements are not the weakest parts of the bearing ...". The database that Palmgren used to benchmark his and later the Lundberg-Palmgren equations were obtained under radially loaded conditions. Under these conditions, the life of the rolling elements as a system (set) will be equal to or greater than that of the outer race. As a result, failure of the rolling elements in determining bearing life was not initially considered by Palmgren. Had it been, equation (13) would have been written as follows:

$$
\left(\frac{1}{L_{10}}\right)^{e}=\left(\frac{1}{L_{i r}}\right)^{e}+\left(\frac{1}{L_{r e}}\right)^{e}+\left(\frac{1}{L_{\text {or }}}\right)^{\boldsymbol{e}}
$$

where the Weibull slope $\boldsymbol{e}$ is the same for each of the components as well as for the bearing as a system.

Comparing equation (16) with equation (13), the value of the $\boldsymbol{L}_{\mathbf{1 0}}$ bearing life will be the same. However, the values of the $\boldsymbol{L}_{\boldsymbol{i r}}$ and $\boldsymbol{L}_{\boldsymbol{o r}}$ between the two equations will not be the same, but the ratio of $\boldsymbol{L}_{\boldsymbol{o r}} / \boldsymbol{L}_{\boldsymbol{i r}}$ will remain unchanged.

The fraction of failures due to the failure of a bearing component is expressed by Johnson (ref. 19) as

$$
\begin{aligned}
& \text { Fraction of inner-race failures }=\left[\frac{L_{s y s}}{L_{i r}}\right]^{e} \\
& \text { Fraction of rolling-element failures }=\left[\frac{L_{s y s}}{L_{r e}}\right]^{e} \\
& \text { Fraction of outer-race failures }=\left[\frac{L_{s y s}}{L_{o r}}\right]^{e}
\end{aligned}
$$

From equations (17a) to (17c), if the life of the bearing and the fractions of the total failures represented by the inner race, the outer race and the rolling element set are known, the life of each of these components can be calculated. Hence, by observation, it is possible to determine the life of each of the bearing components with respect to the life of the bearing.

Equations (17a) to (17c) were verified using radially loaded and thrust-loaded 50-mm-bore ball bearings. Three hundred forty (340) virtual bearing sets totaling 31,400 bearings were randomly assembled and tested by Monte Carlo (random) number generation (ref. 20). From the Monte Carlo 
TABLE IV.-COMPARISON OF BEARING FAILURE DISTRIBUTIONS BASED UPON WEIBULLBASED MONTE CARLO METHOD AND THOSE CALCULATED FROM EQUATIONS (17a) TO (17c) FOR 50-MM-BORE DEEP-GROOVE AND ANGULAR-CONTACT BALL BEARINGS (REF. 20)

\begin{tabular}{|c|l|c|c|}
\hline \multirow{2}{*}{ Ball-bearing type } & \multicolumn{1}{|c|}{ Component } & \multicolumn{2}{|c|}{ Percent failure } \\
\cline { 3 - 4 } & & $\begin{array}{c}\text { Weibull-based Monte } \\
\text { Carlo results }\end{array}$ & $\begin{array}{c}\text { Results from } \\
\text { equations (17a) to (17c) }\end{array}$ \\
\hline \multirow{2}{*}{ Deep-groove } & Inner race & 70.1 & 69.9 \\
\cline { 2 - 4 } & Rolling element & 14.8 & 15.0 \\
\cline { 2 - 4 } & Outer race & 15.1 & 15.0 \\
\hline \multirow{3}{*}{ Angular-contact } & Inner race & 45.4 & 45.1 \\
\cline { 2 - 4 } & Rolling element & 45.2 & 45.1 \\
\cline { 2 - 4 } & Outer race & 9.4 & 9.7 \\
\hline
\end{tabular}

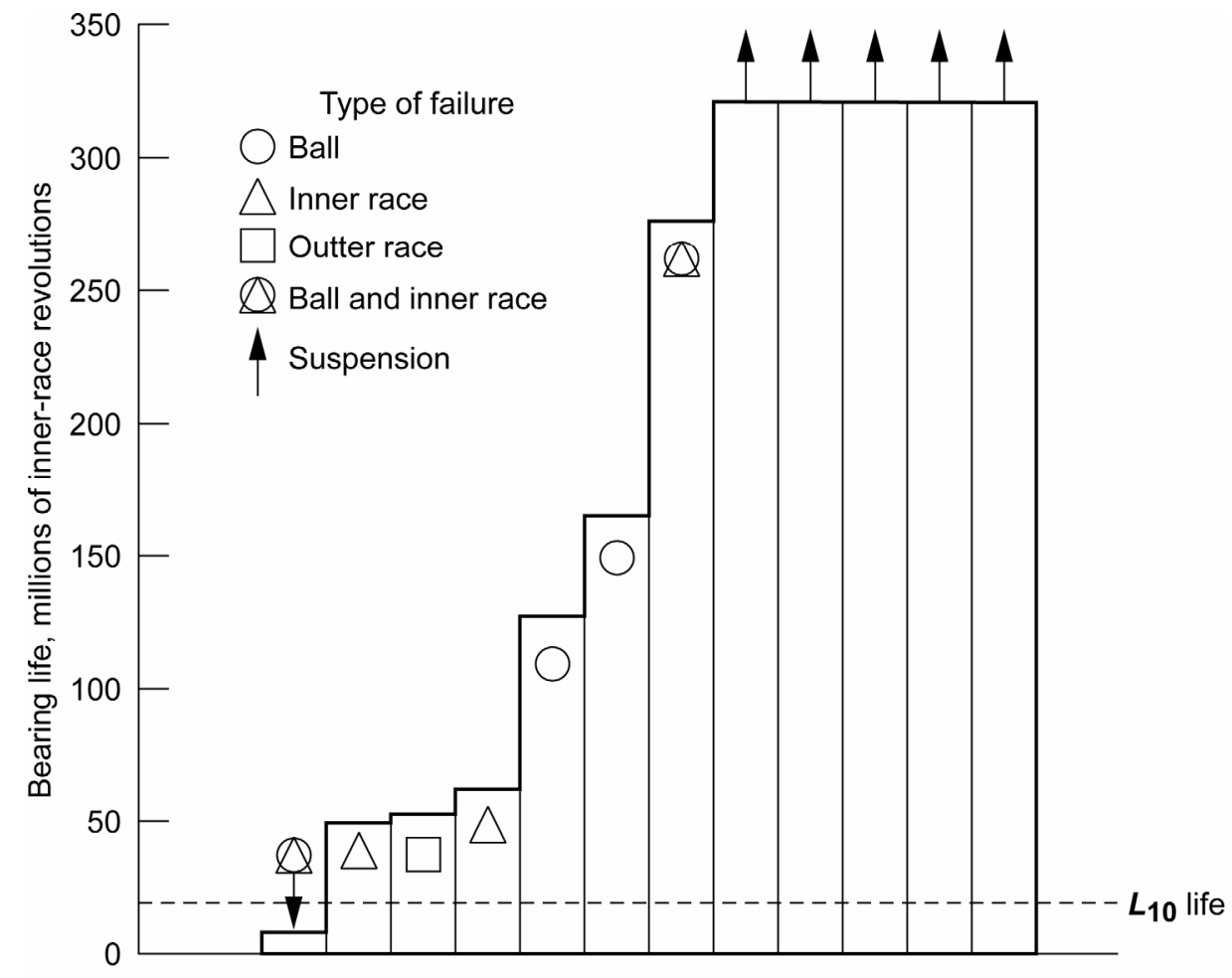

Figure 5.-Rolling element fatigue lives of AISI 52100 204-size angular-contact ball bearings. Contact angle is $10^{\circ}$; outer-race temperature, $79^{\circ} \mathrm{C}\left(175^{\circ} \mathrm{F}\right)$; thrust load, $1108 \mathrm{~N}$ (249 lb); inner-ring speed, $10000 \mathrm{rpm}$; lubricant, MiL-L-7808; $\boldsymbol{L}_{10}$ life, $20.5 \times 10^{6}$ inner-ring revolutions (34.2 hr); and failure index, 7 out of 12 (ref. 21).

simulation the percentage of each component failed was determined and compared to those predicted from equations (17a) to (17c). These results are shown in table IV. There is excellent agreement between these techniques (ref. 20).

Figure 5 summarizes rolling-element fatigue life data for ABEC 7 204-size angular-contact ball bearings made from AISI 52100 steel (ref. 21). The bearings had a free contact angle of $10^{\circ}$. Operating conditions were an inner-ring speed of $10000 \mathrm{rpm}$, an outer-ring temperature of $79^{\circ} \mathrm{C}\left(175^{\circ} \mathrm{F}\right)$, and a thrust load of $1108 \mathrm{~N}$ (249 lb). The thrust load produced maximum Hertz stresses of $3172 \mathrm{MPa}$ (460 ksi) on the inner race and $2613 \mathrm{MPa}(379 \mathrm{ksi})$ on the outer race. From a Weibull analysis of the data, the bearing $\boldsymbol{L}_{\mathbf{1 0}}$ life was 20.5 million inner-race revolutions or approximately $34.2 \mathrm{hr}$ of operation (ref. 21).

Seven of the twelve bearings failed from rolling-element fatigue. Two of the failed bearings had fatigue spalls on a ball and an inner race. Two bearings had inner-race fatigue spalls. Two bearings had 
fatigue spalls on a ball, and one bearing had an outer-race fatigue spall. Counting each component that failed as an individual failure independent of the bearing, there were four inner-race failures, four ball failures, and one outer-race failure for a total of nine failed components. Inner race failures were responsible for 44.4 percent of the failures; ball failures, 44.4 percent; and outer-race failures, 11.2 percent. Using each of these percentages in equations 17(a) to 17(c) together with the experimental $\boldsymbol{L}_{\mathbf{1 0}}$ life, the lives of the inner and outer races and the ball set were calculated. For purposes of the calculation, the Weibull slope $\boldsymbol{e}$ was assumed to be 1.11, the same as Lundberg and Palmgren (ref. 9). The resultant component $\boldsymbol{L}_{\mathbf{1 0}}$ lives were 53 million inner-race revolutions $(88.3 \mathrm{hr})$ for both the inner race and ball set and 183.3 million inner-race revolutions $(305.5 \mathrm{hr})$ for the outer race.

For nearly all rolling-element bearings the number of inner-race failures is greater than those of the outer race. Accordingly, from equations (17a) and (17c), the life of the outer race will be greater than that of the inner race. Zaretsky (ref. 15) noted that for radially loaded bearings (ball or roller), the percent of failures of the rolling-element set was generally equal to and/or less than the outer race. For thrust-loaded ball or roller bearings, Zaretsky (ref. 15) further noted that the percent of the rolling-element set was equal to or less than the inner race but more than the outer race. In order to account for material and processing variations, Zaretsky developed what is now referred to as Zaretsky's Rule (ref. 15) as follows:

For radially loaded ball and roller bearings, the life of the rolling element set is equal to or greater than the life of the outer race. Let the life of the rolling element set (as a system) be equal to that of the outer race.

From equation (16)

$$
\left(\frac{1}{\boldsymbol{L}_{10}}\right)^{\boldsymbol{e}}=\left(\frac{1}{\boldsymbol{L}_{\boldsymbol{i r}}}\right)^{\boldsymbol{e}}+2\left(\frac{1}{\boldsymbol{L}_{\mathrm{or}}}\right)^{\boldsymbol{e}}
$$

where

$$
L_{r e}=L_{o r}
$$

For thrust loaded ball and roller bearings, the life of the rolling element set is equal to or greater than the life of the inner race but less than that of the outer race. Let the life of the rolling-element set (as a system) be equal to that of the inner race.

From equation (16)

$$
\left(\frac{1}{L_{10}}\right)^{e}=2\left(\frac{1}{L_{i r}}\right)^{e}+\left(\frac{1}{L_{o r}}\right)^{e}
$$

where

$$
L_{r e}=L_{i r}
$$

Examples of using equations (18) and (19) are given in reference 15. As previously stated, the resulting values for $\boldsymbol{L}_{i r}$ and $\boldsymbol{L}_{\boldsymbol{o r}}$ from these equations are not the same as those from equation (13). They will be higher.

H. Takata (ref. 22), using a modified approach to the Lundberg-Palmgren theory (ref. 9), derived the basic dynamic load capacity of the rolling-element bearing set in addition to those for the inner and outer races for radial and thrust-loaded ball and roller bearings. For radially loaded ball bearings, Takata (ref. 22) assumes random ball rotation. For thrust-loaded ball bearings, he assumes a single or fixed 
running track on each ball. According to Takata (ref. 22), the basic dynamic load capacity $\boldsymbol{C}_{\boldsymbol{D}}$ of a bearing system can be expressed as

$$
C_{D}=\left(C_{i r}^{-w}+C_{r e}^{-w}+C_{o r}^{-w}\right)^{-1 / w}
$$

where $\boldsymbol{C}_{\boldsymbol{D}}$ is calculated from equations (15a) and (15b) (from Lundberg-Palmgren (ref. 9)), and exponent $\boldsymbol{w}$ is equal to $10 / 3$ for ball bearings. Takata provides equations for calculating the dynamic load capacity of the rolling-element (ball) set, $\boldsymbol{C}_{\boldsymbol{r} e}$. The resulting values for $\boldsymbol{C}_{\boldsymbol{i} r}$ and $\boldsymbol{C}_{\boldsymbol{o r}}$ will be higher than those from the Lundberg-Palmgren equations (ref. 9).

Takata (ref. 22) performed a single ball-set life calculation within his paper for a 30-mm-bore deepgroove ball bearing. From this calculation he concluded that for this bearing

$$
C_{i r}<C_{r e}<C_{o r}
$$

This would imply that

$$
\boldsymbol{L}_{i r}<\boldsymbol{L}_{r e}<\boldsymbol{L}_{\text {or }}
$$

However, he did not validate his example or his equations to determine ball-set or roller-set life with a bearing life data base.

Harris (ref. 23), citing Takata (ref. 22), compared the rolling-element fatigue life of 28.575-mm(1.125-in.-) diameter AISI 52100 and AISI M-50 steel balls in a Pratt \& Whitney one-ball fatigue tester. He ran nine test series, each comprising 12 to 48 balls. The test balls had fixed double running tracks. The maximum Hertz stress ranged from 3980 to $4160 \mathrm{MPa}(577.2$ to $603.3 \mathrm{ksi})$ with most tests run at $4000 \mathrm{MPa}(580.1 \mathrm{ksi})$. The number of rolling-element fatigue failures for each test series varied from 3 to 36. He compared the test results to the Lundberg-Palmgren theory (ref. 9) and to a modified LundbergPalmgren theory (ref. 23) incorporating a "fatigue limit." The fatigue limit that he used for his calculations for both the AISI 52100 and AISI M-50 steels was $175 \mathrm{MPa}(25.4 \mathrm{ksi})$. He concluded that the application of a fatigue limit to the modified Lundberg-Palmgren theory predicted ball lives in the one-ball fatigue tester that correlated well with the measured ball lives. He further concluded that the Lundberg-Palmgren life prediction method modified using currently accepted material-life and lubrication-life factors did not yield a satisfactory correlation.

Zaretsky, Anderson, and Parker (ref. 21) using the NASA five-ball fatigue tester and the Pratt \& Whitney one-ball fatigue tester reported similar work to that of Harris (ref. 23). They also compared their experimental results to the Lundberg-Palmgren dynamic load capacity equations derived for these two test rigs. These comparisons are shown in figure 6. Unlike Harris (ref. 23), it was concluded from these data that, for contact angles up to $30^{\circ}$, the Lundberg-Palmgren capacity equations very nearly predict the thrust capacity for the two test systems. Further, unlike Harris, these results would justify - although not verify - the ball life prediction approach reported by Takata (ref. 22).

In a discussion of Harris's work (ref. 23), S. Pinel and F. Rehman attempted to verify Harris's calculations for the Lundberg-Palmgren life predictions (ref. 23). The ratio of Pinel and Rehman's predicted $\boldsymbol{L}_{\mathbf{1 0}}$ life based on Lundberg-Palmgren to the actual experimental life was 0.70 (ref. 23). This compares to a ratio of 16.3 from Harris's Lundberg-Palmgren calculations (ref. 23), suggesting an error in the Harris analysis. 


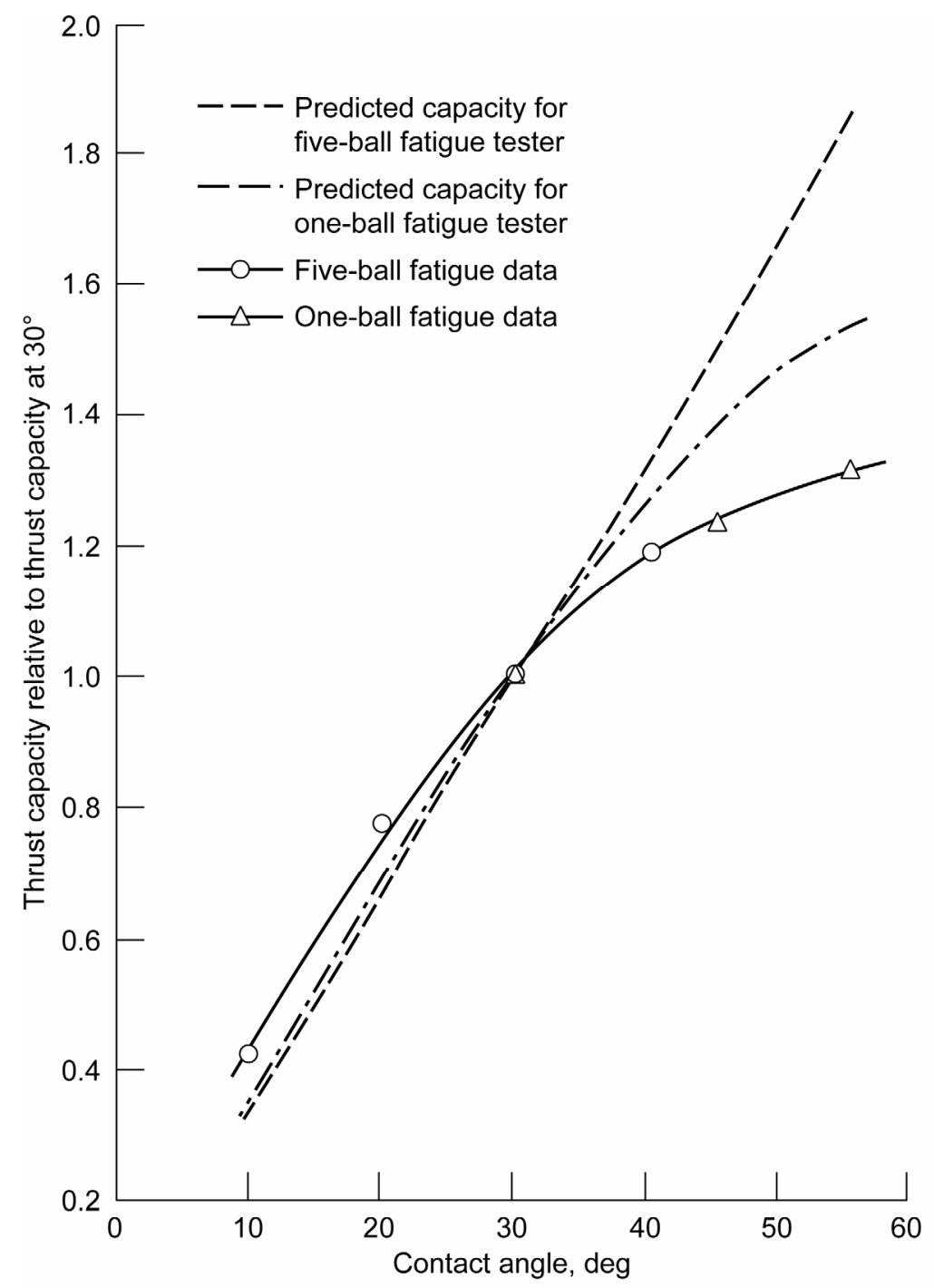

Figure 6.-Comparison of normalized dynamic load capacities of NASA five-ball fatigue tester and Pratt-Whitney one-ball fatigue tester determined experimentally to those predicted from Lundberg-Palmgren equation (ref. 21).

\section{Bearing Life Factors Based on Conformity}

From the above, the life of the bearing can be related to the life of the inner race where the ratio $X$ between the outer- and inner-race lives is known or can be calculated where

$$
X=\frac{L_{o r}}{L_{i r}}
$$

and

$$
L_{o r}=X L_{i r}
$$

The value $\boldsymbol{X}$ can be approximated from equation (22a) and Lundberg and Palmgren (ref. 9) as follows: 


$$
X=\frac{L_{o r}}{L_{i r}}=1.12\left(\frac{1+\frac{d \cos \beta}{d_{e}}}{1-\frac{d \cos \beta}{d_{e}}}\right)^{5.16}
$$

Deep-Groove Ball Bearings-Applying equation (22b) to (18) for radially loaded deep-groove ball bearings, equation (18) becomes

$$
L_{10}=\left(\frac{X^{e} L_{i r}^{e}}{X^{e}+2}\right)^{1 / e}
$$

Applying life factors based on the effect of conformity on the respective lives of the inner and outer races, equation (24) becomes

$$
L_{10_{m}}=\left[\frac{\left(L F_{i r}\right)^{e}\left(L F_{o r}\right)^{e} X L_{i r}^{e}}{\left(L F_{o r}\right)^{e} X^{e}+2\left(L F_{i r}\right)^{e}}\right]^{1 / e}
$$

Dividing equation (25) by equation (24) provides the bearing life factor for the radially loaded deepgroove bearing based on conformity $\boldsymbol{L F}_{\boldsymbol{c}}$ :

$$
L F_{c}=\left[\frac{\left(L F_{i r}\right)^{e}\left(L F_{o r}\right)^{e}\left(X^{e}+2\right)}{\left(L F_{o r}\right)^{e} X^{e}+2\left(L F_{i r}\right)^{e}}\right]^{1 / e}
$$

Angular-Contact Ball Bearings-Applying equation (22b) to equation (19) for deep-groove ball bearings, equation (19) becomes

$$
L_{10}=\left\{\frac{X^{e} L_{i r}^{e}}{2 X^{e}+1}\right\}^{1 / e}
$$

Applying life factors based on the effect of conformity on the respective lives of the inner and outer races, equation (27) becomes

$$
L_{10_{m}}=\left\{\frac{\left[\left(L F_{i r}\right)\left(L F_{o}\right) X L_{i r}\right]^{e}}{2\left(L F_{o r}\right)^{e} X^{e}+\left(L F_{i r}\right)^{e}}\right\}^{1 / e}
$$

Dividing equation (28) by equation (27) provides the bearing life factor $\boldsymbol{L F}_{\mathbf{c}}$ for the thrust-loaded angular-contact ball bearing based on conformity: 
TABLE V.-REPRESENTATIVE RATIOS OF OUTER- TO

INNER-RACE LIFE, $\boldsymbol{L}_{\boldsymbol{o}} / \boldsymbol{L}_{\boldsymbol{i}}$, FOR REPRESENTATIVE BALL BEARING TYPES.

\begin{tabular}{|l|c|c|}
\hline \multicolumn{1}{|c|}{ Bearing type $^{\mathrm{a}}$} & $\frac{\boldsymbol{d} \cos \boldsymbol{\beta}}{\boldsymbol{d}_{\boldsymbol{e}}}$ & $\begin{array}{c}\text { Life ratio, } \\
\boldsymbol{L}_{\boldsymbol{o r}} / \boldsymbol{L}_{\boldsymbol{i r}}\end{array}$ \\
\hline Extremely light & 0.15 & 4.4 \\
\hline Extra light & .18 & 5.9 \\
\hline Light & .23 & 9.6 \\
\hline Medium & .25 & 13.0 \\
\hline Heavy & .28 & 17.7 \\
\hline
\end{tabular}

${ }^{\mathrm{a}}$ See fig. 4.

${ }^{\mathrm{b}}$ From equation (23).

$$
L F_{c}=\left[\frac{\left(L F_{i r}\right)^{e}\left(L F_{o r}\right)^{e}\left(2 X^{\boldsymbol{e}}+1\right)}{2\left(L F_{o r}\right)^{\boldsymbol{e}} \boldsymbol{X}^{\boldsymbol{e}}+\left(\boldsymbol{L} \boldsymbol{F}_{i r}\right)^{\boldsymbol{e}}}\right]^{1 / \boldsymbol{e}}
$$

Representative life factors $\boldsymbol{L} \boldsymbol{F}_{\boldsymbol{i r}}$ and $\boldsymbol{L F}_{\boldsymbol{o r}}$ for ball bearing sizes shown in figure 4 are summarized in table V.

\section{Application to Lundberg-Palmgren Equations}

In order to calculate a life factor $\left(\boldsymbol{L} \boldsymbol{F}_{c}\right)$ based on the conformity of a ball in a nonconforming race groove, it is necessary to obtain from the bearing manufacturer's catalog the bearing outside diameter (OD), inside diameter (ID), free contact angle $\boldsymbol{\beta}$ and ball diameter $\boldsymbol{d}$. Knowing the bearing OD and ID, calculate the pitch diameter $\boldsymbol{d}_{e}$ from equation (2). From these values, the ratio of the outer to inner race lives $\boldsymbol{X}$ can be calculated either from equation (20) or from an appropriate bearing computer program where the inner-and outer-race conformities are the same.

From table I, life factors $(\boldsymbol{L F})$ based on individual race conformities are obtained for both the inner and outer races. These LF values are normalized to a ball-race conformity $(f)$ of 0.52 . Depending on whether the bearing is a deep-groove or angular-contact ball bearing, these values together with that for the race-life ratio $\boldsymbol{X}$ are used in equations (26) or (29), respectively, to calculate bearing life factor $\boldsymbol{L F}_{\boldsymbol{c}}$ based on the combined inner- and outer-race conformities. These values of $\boldsymbol{L F}_{\boldsymbol{c}}$ can then be applied against the bearing catalog life or the values calculated from equations (14), (15a), and (15b).

For the bearing series shown in figure 4 and summarized in table $\mathrm{V}$, representative life factors were calculated for deep-groove and angular-contact ball bearings using equations (26) and (29), respectively, with race conformities ranging from 0.505 to 0.57 . The conformity of one race was fixed at 0.52 and the other race was allowed to vary and vice versa. The results were normalized for the conformity combination of 0.52 inner and 0.52 outer, where the resultant bearing life factor for conformity $\boldsymbol{L F}_{\boldsymbol{c}}$ is equal to 1 . These results were compared to those generated from the Lundberg-Palmgren equations from reference (ref. 9). The Lundberg-Palmgren equations are the same for deep-groove and angular-contact ball bearings except for the inclusion of the cosine of the contact angle $\boldsymbol{\beta}$. Where $\cos \boldsymbol{\beta}=1$, the results for the two types of ball bearings are identical.

Table VI shows a comparison of these life factors for extreme combinations of conformities for extremely light and heavy series ball bearings. The results for both bearing types are different from that calculated from the Lundberg-Palmgren equations. Depending on the bearing type and series as well as conformity combinations, the calculated life for deep-groove ball bearings can be over 40 percent less than that calculated by the Lundberg-Palmgren equations. For angular-contact ball bearings, the life can vary from 22 to -39 percent from that calculated by the Lundberg-Palmgren equations. 
TABLE VI.-COMPARISON OF LIFE FACTORS BASED ON COMBINATIONS OF BALL-RACE CONFORMITIES NORMALIZED TO INNER- AND OUTER-RACE CONFORMITIES OF 0.52

\begin{tabular}{|c|c|c|c|c|c|c|c|}
\hline \multirow{3}{*}{$\begin{array}{c}\text { Ball bearing } \\
\text { series } \\
\text { (see table V } \\
\text { and fig. 4) }\end{array}$} & \multicolumn{2}{|c|}{ Ball-race conformity } & \multicolumn{5}{|c|}{$\begin{array}{l}\text { Bearing life factor for conformity, } \\
\qquad \boldsymbol{L F}_{\boldsymbol{c}}\end{array}$} \\
\hline & \multirow[t]{2}{*}{ Inner race } & \multirow[t]{2}{*}{ Outer race } & \multirow[b]{2}{*}{$\begin{array}{l}\text { Lundberg- } \\
\text { Palmgren } \\
\text { results for } \\
\text { deep-groove } \\
\text { and angular- } \\
\text { contact } \\
\text { bearing } \\
\text { (ref. 9) }\end{array}$} & \multicolumn{2}{|c|}{ Deep-groove ball bearing } & \multicolumn{2}{|c|}{ Angular-contact ball bearing } \\
\hline & & & & $\begin{array}{c}\text { From } \\
\text { equation }(26)\end{array}$ & $\begin{array}{l}\text { Change from } \\
\text { Lundberg- } \\
\text { Palmgren, } \\
\text { percent }\end{array}$ & $\begin{array}{c}\text { From } \\
\text { equation (29) }\end{array}$ & $\begin{array}{l}\text { Change from } \\
\text { Lundberg- } \\
\text { Palmgren, } \\
\text { percent }\end{array}$ \\
\hline \multirow{4}{*}{$\begin{array}{l}\text { Extremely } \\
\text { light }\end{array}$} & 0.505 & 0.52 & 3.02 & 2.22 & -27 & 3.37 & 12 \\
\hline & .57 & .52 & .27 & .16 & -41 & .17 & -37 \\
\hline & .52 & .505 & 1.14 & 1.13 & -1 & 1.07 & -6 \\
\hline & .52 & .57 & .65 & .41 & -37 & .68 & 5 \\
\hline \multirow[t]{4}{*}{ Heavy } & .505 & .52 & 3.60 & 3.49 & -3 & 4.17 & 16 \\
\hline & .57 & .52 & .26 & .17 & -39 & .16 & -39 \\
\hline & .52 & .505 & 1.09 & 1.06 & -3 & 1.02 & -6 \\
\hline & .52 & .57 & .74 & .71 & -4 & .90 & 22 \\
\hline
\end{tabular}

While the trend between bearing life factors are qualitatively similar, they are quantitatively different between the angular-contact ball bearings and the deep-groove ball bearings. Comparing the two bearing types, the life factors $\boldsymbol{L} \boldsymbol{F}_{c}$ for the deep-groove bearings can be as much as 34 percent lower than that for angular-contact ball bearings.

\section{Other Bearing Life Methods}

From equation (10), Lundberg-Palmgren (ref. 9) have bearing life inversely proportional to the orthogonal shearing stress $\tau_{\boldsymbol{o}}$ raised to the $\boldsymbol{c} / \boldsymbol{e}$ power where

$$
\boldsymbol{L} \sim 1 /\left(\boldsymbol{\tau}_{\boldsymbol{o}}\right)^{\boldsymbol{c} / \boldsymbol{e}}
$$

From Lundberg and Palmgren (ref. 9) the value of $\boldsymbol{c} / \boldsymbol{e}$ for ball bearings is 9.3. Lundberg and Palmgren (ref. 9) assumed that the orthogonal shearing stress $\boldsymbol{\tau}_{\boldsymbol{o}}$ is the critical stress related to and affecting rollingelement fatigue. However, other shearing stresses designated $\boldsymbol{\tau}$ that are proportional to the maximum Hertz stress, such as maximum shearing stress, octahedral shearing stress, and von Mises equivalent stress, are also related to and affect rolling-element fatigue. As a result, equation (30a) can be written as

$$
\boldsymbol{L} \sim 1 /(\boldsymbol{\tau})^{c / e}
$$

Incorporating a fatigue limit $\tau_{\ell}$ in equation (30b),

$$
\boldsymbol{L} \sim 1 /\left(\boldsymbol{\tau}-\boldsymbol{\tau}_{\ell}\right)^{c / e}
$$

\section{Background}

In recent years there has been a movement to incorporate the concept of a "fatigue limit" in the Lundberg-Palmgren equations (ref. 9). The fatigue limit as applied to ball and roller bearings is a shearing stress below which no rolling-element fatigue should occur. The concept of a fatigue limit for rollingelement bearings was proposed by Palmgren in 1924 (ref. 4). It was apparently abandoned by him first in 1945 (ref. 5) and then again with Lundberg in 1947 (ref. 9). In 1985, Ioannides and Harris (ref. 24) applied Palmgren's concept of a fatigue limit to the Lundberg-Palmgren equations in the form shown in 
equation (31). The ostensible reason Ioannides and Harris used the fatigue limit was to replace the material and processing life factors (ref. 15) that are used as life modifiers in conjunction with the bearing lives calculated from the Lundberg-Palmgren equations (ref. 15).

There are two problems associated with the use of a fatigue limit for rolling-element bearings. The first problem is that the form of equation (30c) may not reflect the presence of a fatigue limit but the presence of a compressive residual stress (ref. 15). The second problem is that there are no data in the open literature that would justify the use of a fatigue limit for through-hardened bearing steels such as AISI 52100 and AISI M-50. In fact, a paper presented by Tosha et al. (ref. 25), reporting the results of rotating beam fatigue experiments for through-hardened AISI 52100 steel at very low stress levels, shows conclusively that a fatigue limit does not exist for this bearing steel.

Recent publications by the ASME (ref. 26) and the ISO (refs. 27 and 28) for calculating the life of rolling-element bearings include a fatigue limit and the effects of ball-race conformity on bearing fatigue life. These methods do not, however, include the effect of ball failure on bearing life. The ISO method is based on the work reported by Ioannides, Bergling, and Gabelli (ref. 29). The ASME method as contained in their proposed ASMELIFE software (ref. 26) uses the von Mises stress as the critical stress with a fatigue limit value of $684 \mathrm{MPa}(99,180 \mathrm{psi})$. This corresponds to a Hertz surface contact stress of $1140 \mathrm{MPa}(165,300 \mathrm{psi}$ ). The ISO 281:2006 (ref. 28) method uses a fatigue limit stress of $900 \mathrm{MPa}$ $(130,500 \mathrm{psi})$, which corresponds to a Hertz contact stress of $1500 \mathrm{MPa}(217,500 \mathrm{psi})$.

The concept of a fatigue limit load (bearing load under which the fatigue stress limit is just reached in the most heavily loaded raceway contact) introduced in the proposed (revised) ISO rating methods is proportional to the fatigue limit stress raised to the 3 rd power for ball bearings (point contact). These differing values of stress would result in a 128 percent higher load using ISO 281:2006 (ref. 28) than ASMELIFE (ref. 26) below which no fatigue failure would be expected to occur.

The effect of using different values of fatigue limit or no fatigue limit on rolling-element fatigue life prediction is shown in table VII. This table summarizes the qualitative results obtained for maximum Hertz stresses of 1379, 1724, and $2068 \mathrm{MPa}(200,250$, and $300 \mathrm{ksi})$ for point contact using equation (30) for Lundberg-Palmgren without a fatigue limit and equation (30c) for fatigue limits of $684 \mathrm{MPa}$ $(99,180 \mathrm{psi})$ (from ASMELIFE) and $900 \mathrm{MPa}$ (130,500 psi) (from ISO 281:2006). The results are normalized to a maximum Hertz stress of $1379 \mathrm{MPa}(200 \mathrm{ksi})$ with no fatigue limit where the quotient of equation (30c) divided by equation (30b) is taken to the c/e power of 9.3 (taken from Lundberg and Palmgren). The effect of stressed volume was also factored into these calculations.

TABLE VII.-EFFECT OF FATIGUE LIMIT $\boldsymbol{\tau}$ ON ROLLING-ELEMENT FATIGUE LIFE

\begin{tabular}{|c|c|c|c|}
\hline \multirow{3}{*}{$\begin{array}{c}\text { Fatigue limit, }^{\mathrm{a}} \\
\boldsymbol{\tau}_{\boldsymbol{l}} \\
\mathrm{MPa}(\mathrm{ksi})\end{array}$} & \multicolumn{3}{|c|}{ Relative life $^{b, c}$} \\
\hline & \multicolumn{3}{|c|}{$\begin{array}{c}\text { Maximum Hertz stress, } \\
\text { MPa (ksi) }\end{array}$} \\
\hline & $1379(200)$ & $1724(250)$ & $2068(300)$ \\
\hline 0 (0), Lundberg-Palmgren (ref. 9) & 1 & 0.134 & 0.026 \\
\hline 684 (99.2), ASMELIFE (ref. 26) & $11.9 \times 10^{6}$ & 3152 & 44.6 \\
\hline 900 (130.5), ISO281-2006 (ref. 28) & $\infty$ & $23.3 \times 10^{6}$ & 4258 \\
\hline
\end{tabular}

${ }^{\mathrm{a}}$ von Mises stress.

${ }^{\mathrm{b}}$ Includes effect of stressed volume.

${ }^{\mathrm{c}}$ Normalized to life at maximum Hertz stress of $1379 \mathrm{MPa}(200 \mathrm{ksi})$ with no fatigue limit. 


\section{Comparison of Results}

Figures 7 and 8 show the comparison of ball set life and race conformity on bearing life for radially loaded vacuum-arc-remelted (VAR) AISI 52100 steel, 60-mm-bore, ball bearings under pure radial and thrust loads. Bearing geometry, operating parameters, and life factors used for these calculations are summarized in table VIII.
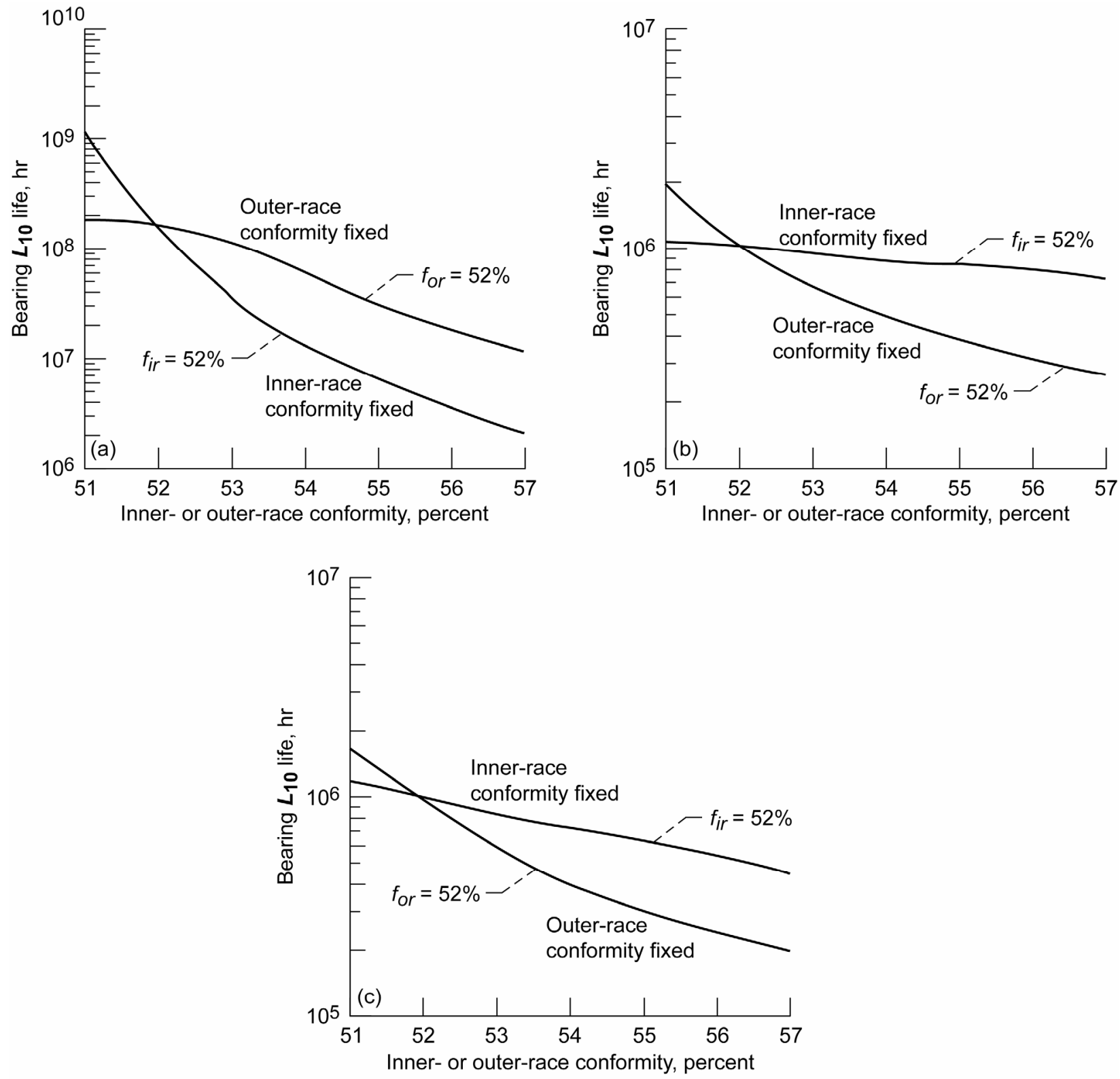

Figure 7.-Effect of ball set life and race conformity on calculated bearing life using ASMELIFE, Lundberg-Palmgren equations, and Zaretsky's Rule. Bearing type, 60-mm-bore ball bearing; contact angle, $0^{\circ}$; radial load, $2224 \mathrm{~N}$ (500 lb); speed, 3600 rpm; and material, VAR AISI 52100 steel. (a) ASMELIFE with fatigue limit (ISO 281/2 (ref. 27)) and without ball set life. (b) Lundberg-Palmgren (ref. 9) and ISO 281:1990(E) (ref. 12) with life factors (ref. 15) and without ball set life. (c) Lundberg-Palmgren (ref. 9) and ISO 281:1990(E) (ref. 12) modified by ball set life (Eq. (26)) and with life factors (15). 

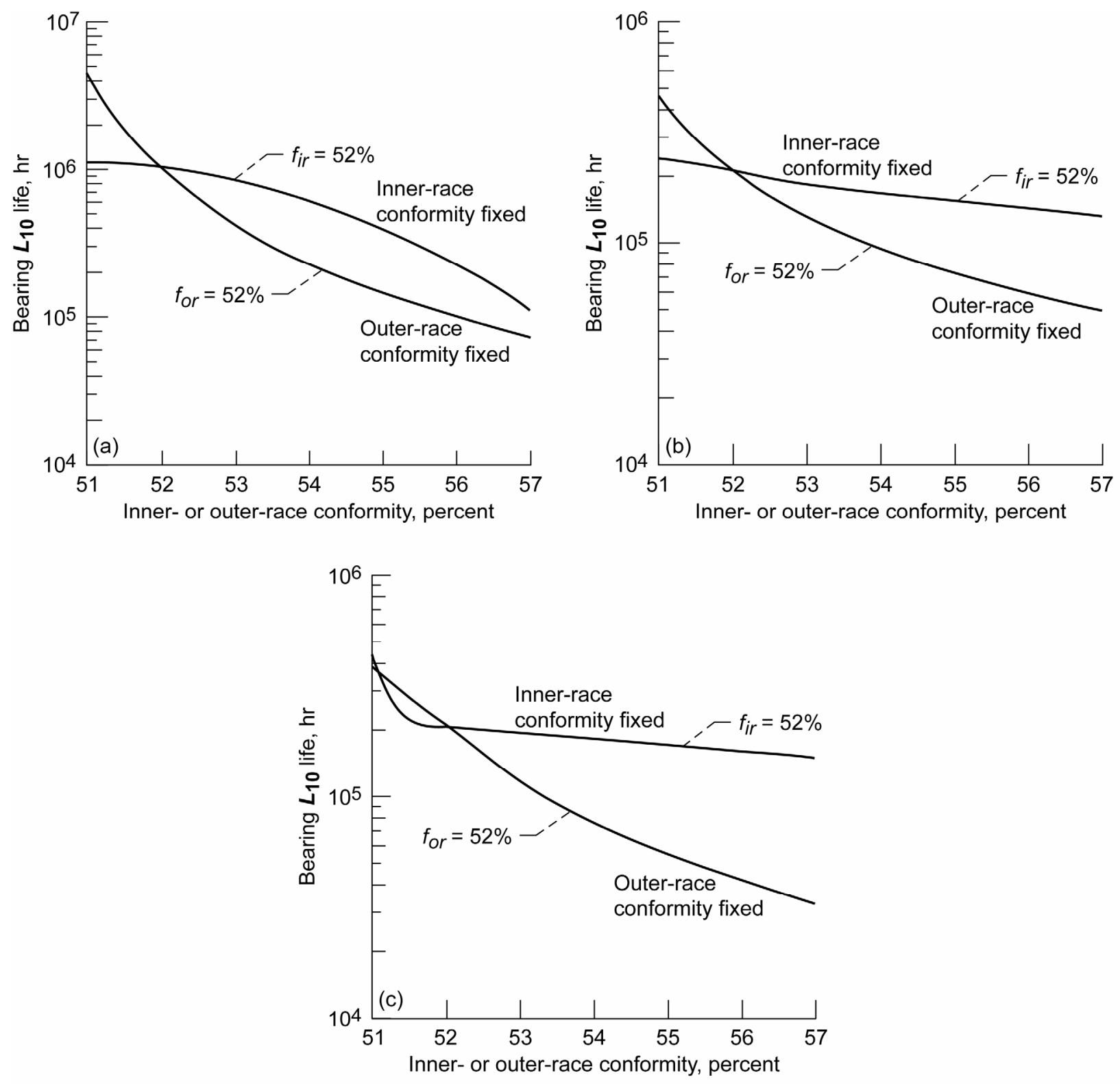

Figure 8.-Effect of ball set life and race conformity on calculated bearing life using ASMELIFE, Lundberg-Palmgren equations, and Zaretsky's Rule. Bearing type, $60-\mathrm{mm}$ bore ball bearing; contact angle, $25^{\circ}$; thrust load, $4448 \mathrm{~N}$ (1000 lb); speed, $3600 \mathrm{rpm}$; and material, VAR AISI 52100 steel. (a) ASMELIFE with fatigue limit (ISO 281/2 (ref. 27)) and without ball set life. (b) Lundberg-Palmgren (ref. 9) and ISO 281:1990(E) (ref. 12) with life factors (ref. 15) and without ball set life. (c) Lundberg-Palmgren (ref. 9) and ISO 281:1990(E) (ref. 12) modified by ball set life (Eq. (ref. 29)) and with life factors (15). 
TABLE VIII.-BALL BEARING GEOMETRY, OPERATING PARAMETERS, AND LIFE FACTORS FOR BEARING LIFE CALCULATIONS

\begin{tabular}{|c|c|c|}
\hline Bearing information & $\begin{array}{c}\text { Radially loaded } \\
\text { bearing }\end{array}$ & $\begin{array}{c}\text { Thrust-loaded } \\
\text { bearing }\end{array}$ \\
\hline \multicolumn{3}{|l|}{ Ball bearing geometry: } \\
\hline Bore, mm (in.) & $60(2.362)$ & $60(2.362)$ \\
\hline Outside diameter, $\mathrm{mm}$ (in.) & $110(4.331)$ & $110(4.331)$ \\
\hline Width, mm (in.) & $22(0.866)$ & $22(0.866)$ \\
\hline Ball diameter, mm (in.) & $16(0.625)$ & $16(0.625)$ \\
\hline Number of balls & 10 & 10 \\
\hline \multicolumn{3}{|l|}{ Surface finish, $\mu \mathrm{m}$ ( $\mu$ in. $), \mathrm{AA} \mathrm{a}^{\mathrm{a}}$} \\
\hline Races & $0.1(4)$ & $0.1(4)$ \\
\hline Balls & $0.025(1)$ & $0.025(1)$ \\
\hline Surface composite finish, $\mu \mathrm{m}(\mu$ in. $), \mathrm{AA}^{\mathrm{a}}$ & $0.103(4.123)$ & $0.103(4.123)$ \\
\hline Free contact angle, degrees & 0 & 25 \\
\hline Material $^{\mathrm{b}}$ & VAR AISI 52100 & VAR AISI 52100 \\
\hline \multicolumn{3}{|l|}{ Operating parameters: } \\
\hline Speed, rpm & 3600 & 3600 \\
\hline Load, N (lb) & $2224(500)$ & $4448(1000)$ \\
\hline Inner-race stress at 52 percent conformity, $\mathrm{MPa}(\mathrm{ksi})$ & $1544(224)$ & $1544(244)$ \\
\hline Outer-race stress at 52 percent conformity, $\mathrm{MPa}(\mathrm{ksi})$ & $1324(192)$ & $1324(192)$ \\
\hline $\begin{array}{l}\text { Dynamic load capacity, } \boldsymbol{C}_{p} \text { at } 52 \text { percent inner- and outer-race } \\
\text { conformities, N (lb) }\end{array}$ & $40343(9070)$ & $37279(8381)$ \\
\hline $\begin{array}{l}\text { Ratio of outer-race life to inner-race life at } 52 \text { percent inner- } \\
\text { and outer-race conformities }\end{array}$ & 5.843 & 5.576 \\
\hline \multicolumn{3}{|l|}{ Life factors $(\boldsymbol{L F})$ for Lundberg-Palmgren life analysis: } \\
\hline \multicolumn{3}{|l|}{ Material and processing, $\boldsymbol{a}_{2}$ : } \\
\hline Material, AISI 52100 & 3 & 3 \\
\hline Processing, $\mathrm{VAR}^{\mathrm{b}}$ & 3 & 3 \\
\hline \multicolumn{3}{|l|}{ Operating conditions, $\boldsymbol{a}_{3}$ : } \\
\hline $\mathrm{EHD}^{\mathrm{c}}$ film thickness/surface composite finish, $\Lambda$ ratio $=7$ & 3 & 3 \\
\hline Oil filtration, $3 \mu \mathrm{m}$ & 1.4 & 1.4 \\
\hline $\boldsymbol{L F}=\boldsymbol{a}_{2} \times \boldsymbol{a}_{3}=3 \times 3 \times 3 \times 1.4=37.8$ & 37.8 & 37.8 \\
\hline \multicolumn{3}{|l|}{ Life factors $(\boldsymbol{L F})$ for ASMELIFE: } \\
\hline Fatigue limit, $\mathrm{MPa}(\mathrm{ksi})$ von Mises & $684(99.2)$ & $684(99.2)$ \\
\hline \multicolumn{3}{|l|}{ Operation conditions, $\boldsymbol{a}_{3}$ : } \\
\hline $\mathrm{EHD}^{\mathrm{c}}$ film thickness/ surface composite finish, $\Lambda$ ratio $=7$ & 3 & 3 \\
\hline Oil contamination factor & 0.7863 & 0.7863 \\
\hline $\boldsymbol{L F}=3 \times 0.7863=2.36$ & 2.36 & 2.36 \\
\hline
\end{tabular}

For each figure set of figures 7 and 8 , there are two curves. One curve represents the conformity of the outer race constant at 0.52 (52 percent) and the inner-race conformity varied from 0.51 to 0.57 (51 to 57 percent). This will be referred to as "constant outer-race conformity." For the second curve, the innerrace conformity was held constant at 52 percent and the outer-race conformity was varied from 51 to 57 percent. This will be referred to as "constant inner-race conformity."

Figures 7(a) and 8(a) show the results for the ASMELIFE (ref. 26) calculation for the radially loaded and thrust-loaded bearings, respectively. For the radially loaded bearing with constant outer-race conformity, life decreased by 93 percent when the inner-race conformity was varied from 52 to 57 percent (fig. 7(a)). For constant inner-race conformity, the calculated life decreased by 99 percent (fig. 7(a)). Contrary to what would be intuitively expected, the lives obtained for constant outer-race conformity exceeded those lives calculated for constant inner-race conformity. The opposite result should have occurred, suggesting an error in the ASMELIFE computer program. 
For the thrust-loaded bearing (fig. 8(a)), the lives obtained for constant inner-race conformity exceeded those lives calculated for constant outer-race conformity. For constant outer-race conformity, life decreased by 93 percent when the inner-race conformity was varied from 52 to 57 percent. For constant inner-race conformity, the calculated life decreased by 82 percent.

Figures 7(b) and 8(b) show the calculated life results from classical Lundberg-Palmgren theory (ref. 9) and ISO 281 (ref. 12) with life factors but without ball set life for the radially and thrust-loaded bearings, respectively. For the radially loaded bearing with constant outer-race conformity (fig. 7(b)), life decreased by 74 percent when the inner-race conformity was varied from 52 to 57 percent. For constant inner-race conformity, the calculated life decreased by 28 percent when the outer-race conformity was varied from 52 to 57 percent. For the thrust-loaded bearing with constant outer-race conformity (fig. (8(b)), life decreased by 77 percent when the inner-race conformity was varied from 52 to 57 percent. For constant inner-race conformity, the calculated life decreased by 39 percent when the outer-race conformity was varied from 52 to 57 percent.

Figures 7(c) and 8(c) show the life results from classical Lundberg-Palmgren theory (ref. 9) factoring in ball set life using equations (26) and (29) with life factors. For the radially loaded bearing with constant outer-race conformity (fig. 7(c)), life decreased by 81 percent when the inner-race conformity was varied from 52 to 57 percent. For constant inner-race conformity, the calculated life decreased by 55 percent when the outer-race conformity was varied from 52 to 57 percent. For the thrust-loaded bearing with constant outer-race conformity (fig. (8(c)), life decreased by 83 percent when the inner-race conformity was varied from 52 to 57 percent. For constant inner-race conformity, the calculated life decreased by 27 percent when the outer-race conformity was varied from 52 to 57 percent.

Comparing the results from classical Lundberg-Palmgren theory (ref. 9) and ISO 281 (ref. 12) to those from ASMELIFE (ref. 26), for a radially loaded bearing at inner- and outer-race conformities of 52 percent, ASMELIFE calculated a life 17,175 percent greater than that obtained from LundbergPalmgren and ISO 281 with life factors. For a thrust-loaded bearing with inner- and outer-race conformities of 52 percent, ASMELIFE calculated a life 385 percent greater than that obtained from Lundberg-Palmgren and ISO 281 with life factors.

At inner-race conformity of 57 percent and outer-race conformity of 52 percent for a radially-loaded bearing, ASMELIFE calculated a life 4,235 percent greater than that obtained from Lundberg-Palmgren and ISO 281 with life factors. For a thrust-loaded bearing, this amount was 49 percent. At inner-race conformity of 52 percent and outer-race conformity of 57 percent for the radially loaded bearing, ASMELIFE calculated a life 188 percent greater than that obtained from Lundberg-Palmgren and ISO 281 with life factors. For the thrust-loaded bearing, this amount was 42 percent.

When comparing results calculated from the Lundberg-Palmgren theory (ref. 9) incorporating ball set life (figs. (7(c) and 8(c)) to those that did not (figs. 7(b) and 8(b)), the lives at inner- and outer-race conformities of 52 percent are assumed to be equal for the specified operating condition. As the conformity is increased, differences in life emerge as a result of ball set life. At conformities greater than 52 percent, including the life of the ball set results in a lower life prediction than that obtained from the Lundberg-Palmgren equations (figs. 7(b) and (c)). At an inner-race conformity of 52 percent and outerrace conformity of 57 percent for the radially loaded bearing (fig. 7), the life of the bearing considering ball set life is 36 percent less than that calculated from the Lundberg-Palmgren equations without ball set life. At an outer-race conformity of 52 percent and inner-race conformity of 57 percent for a radially loaded bearing (fig. 7), the life of the bearing with ball set life is 25 percent less than that calculated from the Lundberg-Palmgren equations without ball set life.

For the thrust-loaded bearing (figs. 8(b) and (c)) at inner-race conformity of 52 percent and outer-race conformity of 57 percent, the calculated life of the bearing factoring in ball set life (fig. 8(c)) is 19 percent less than calculated from the Lundberg-Palmgren equations without ball set life (fig. 8(b)). At outer-race conformity of 52 percent and inner-race conformity of 57 percent, the life of the bearing factoring in ball set life (fig. 8(c)) is 27 percent less than calculated from the Lundberg-Palmgren equations without ball set life (fig. 8(b)). 
Under the range of stresses examined, the use of a fatigue limit would suggest that (for most operating conditions under which a ball bearing will operate) the bearing will not fail from classical rolling-element fatigue. Realistically, this does not occur. The use of a fatigue limit from either ASMELIFE (ref. 26) or ISO 281:2006 (ref. 28) will significantly over predict bearing life over a range of normal operating Hertz stresses. (The use of ISO 281:2006 in these calculations would result in a bearing life approaching infinity.) Since the predicted lives of rolling-element bearings are high, the problem can become one of undersizing a bearing for a particular application.

\section{Summary of Results}

G. Lundberg and A. Palmgren in 1947 established the primary relation between bearing geometry and bearing life. These relations have been incorporated into both the ANSI/ABMA and the ISO Standards to predict bearing life as well as current life prediction bearing codes. The Lundberg-Palmgren equations only relate to the lives of the inner and outer races and incorporate ball life into their analysis by inference. It has since been recognized that the life of the ball set in relation to the races is different for a deep-groove ball bearing and an angular-contact ball bearing as well as being dependent on the relative contact (Hertz) stresses at the inner and outer races. The analysis reported herein considers the life of the ball set as well as the respective lives of the races and to reassess the effect of ball-race conformity on ball bearing life. The related changes in ball bearing life are incorporated in life factors that can be used to modify the bearing predicted life using the Lundberg-Palmgren equations and the ANSI/ABMA and ISO Standards. The following results were obtained:

1. Two simple algebraic relationships that incorporated ball set life were established to calculate life factors $\left(\boldsymbol{L F}_{c}\right)$ incorporating ball set life to determine the effect inner- and outer-race conformity combinations have on bearing $\boldsymbol{L}_{\mathbf{1 0}}$ life for deep-groove and angular-contact ball bearings, respectively.

2. Depending on the bearing type and series as well as conformity combinations, the calculated life for deep-groove ball bearings can be over 40 percent less than that calculated by the LundbergPalmgren equations. For an angular-contact ball bearing, the life can vary from 16 to -39 percent from that calculated by the Lundberg-Palmgren equations.

3. The trend between bearing life factors are qualitatively similar but quantitatively different between angular-contact and the deep-groove ball bearings. Comparing the two bearing types, the life factors $\boldsymbol{L} \boldsymbol{F}_{\boldsymbol{c}}$ for the deep-groove bearings can be as much as 40 percent lower than that for angular-contact ball bearings.

4. The use of a fatigue limit from either ASMELIFE or ISO 281:2006 can significantly overpredict bearing life over a range of normal operating Hertz stresses, which can result in the selection of undersized bearings for a particular application.

\section{References}

1. Stribeck, R. (1907), "Reports From the Central Laboratory for Scientific Investigation," 1900, Translation by H. Hess, ASME Trans., 29, pp. 420-466.

2. Goodman, J. (1912), "Roller and Ball Bearings," Minutes of the Proceedings, 189, pp. 82-127.

3. Colvin, Fred Herbert; and Stanley, Frank Arthur (1914), American Machinists' Handbook and Dictionary of Shop Terms," Second ed., McGraw-Hill, New York, NY, pp. 381-386.

4. Palmgren, A. (1924), "Die Lebensdauer von Kugellagern (The Service Life of Ball Bearings)," Z. Ver. Devt. Ingr., 68, 14, pp. 339-341.

5. Palmgren, Arvid (1945), Ball and Roller Bearing Engineering, Translation by Gunnar Palmgren and Bryce Ruley, SKF Industries, Philadelphia, PA.

6. Weibull, Waloddi (1939), "A Statistical Theory of the Strength of Materials," Ingeniorsvetenskapsakademiens Handlingar, 151, Stockholm, Sweden. 
7. Weibull, W. (1939), “The Phenomenon of Rupture in Solids," Ingeniorsvetenskapsakademiens Handlingar, 153, Stockholm, Sweden.

8. Thomas, Howard Rice; and Hoersch, Victor A. (1930), "Stresses Due to the Pressure of One Elastic Solid Upon Another With Special Reference to Railroad Rails," Engineering Experiment Station Bulletin 212, Univ. of Illinois, Urbana.

9. Lundberg, G., and Palmgren, A. (1947), "Dynamic Capacity of Rolling Bearings," Acta Polytechnica Mechanical Engineering Series, 1, 10, Stockholm, Sweden.

10. Lundberg, G., and Palmgren, A. (1952), "Dynamic Capacity of Roller Bearings," Ingeniorsvetenskapsakademiens Handlingar, 210, Stockholm, Sweden.

11. Hertz, H. (1895), "Ueber die Beruehrung elastischer Koerper (On Contact of Elastic Bodies)," Gesammelte Werke (Collected Works), 1, Leipzig, Germany.

12. International Organization for Standardization (1990), "Rolling Bearing-Dynamic Load Ratings and Rating Life," ISO281, Geneva.

13. American Bearing Manufacturers Association (1990), "Load Ratings and Fatigue Life for Ball Bearings," ABMA-9, Washington, DC.

14. American Bearing Manufacturers Association (1990), "Load Ratings and Fatigue Life for Roller Bearings," ABMA-11, Washington, DC.

15. Zaretsky, Erwin V. (1992), STLE Life Factors for Rolling Bearings, STLE SP-34, Society of Tribologists and Lubrication Engineers, Park Ridge, IL.

16. Jones, A. Burton (1946), "Analysis of Stresses and Deflections," New Departure Engineering Data; Analysis of Stresses and Deflections, 1, 2, New Departure Division, General Motors Corp., Bristol, CT.

17. American Bearing Manufacturers Association (1992), "Instrument Ball Bearings-Metric Design," ANSI/ABMA-12.1, Washington, DC.

18. American Bearing Manufacturers Association (1992), "Instrument Ball Bearings-Inch Design," ANSI/ABMA-12.2, Washington, DC.

19. Johnson, Leonard Gustave (1964), “The Statistical Treatment of Fatigue Experiments," Elsevier Publishing Co., Amsterdam.

20. Vlcek, Brian L., Hendricks, Robert C., and Zaretsky, Erwin V. (2003), "Determination of RollingElement Fatigue Life From Computer Generated Bearing Tests," Tribol. Trans, 46, 4, pp. 479-493.

21. Zaretsky, Erwin V., Anderson, William J., and Parker, Richard J. (1962), "The Effect of Contact Angle on Rolling-Contact Fatigue and Bearing Load Capacity," ASLE Trans., 5, 1, pp. 210-219.

22. Takata, H. (1992), "A Fatigue Life Theory of Rolling Bearings Considering the Fatigue Life of Rolling Elements," Japanese J. Tribology, 37, 12, pp. 1605-1621.

23. Harris, T.A. (1997), "Prediction of Ball Fatigue in a Ball/V-Ring Test Rig," J. Tribol. Trans. ASME, 119, 3, pp. 365-374.

24. Ioannides, E., and Harris, T.A. (1985), "New Fatigue Life Model for Rolling Bearings," J. Tribol. Trans. ASME, 107, 3, pp. 367-378.

25. Tosha, K., Ueda, D., Shimoda, H., and Shimizu, S., (2006) "A Study on P-S-N Curve for Rotating Bending Fatigue Test for Bearing Steel," Paper presented at 61st STLE Annual Meeting \& Exhibition, May 7-11, 2006, Calgary, Alberta, Canada.

26. ASME Tribology Division (2003), Life Ratings for Modern Rolling Bearings: A Design Guide for the Application of International Standard ISO 281/2, American Society of Mechanical Engineers, New York, NY.

27. International Organization for Standardization (2000), "Rolling Bearings — Dynamic Load Ratings and Rating Life," ISO281, Geneva.

28. ISO 281:2006 (2006), "Rolling Bearings-Dynamic Load Ratings and Rating Life," International Organization for Standardization, Geneva. (To be published).

29. Ioannides, E., Bergling, G., Gabelli, A. (1999), "An Analytical Formulation for the Life of Rolling Bearings," Acta Polytechnica Scandinavica, Mechanical Engineering Series, 137, Finland. 


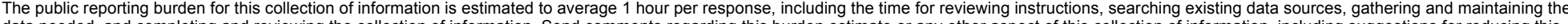

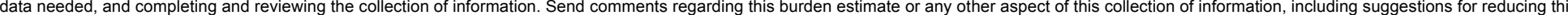

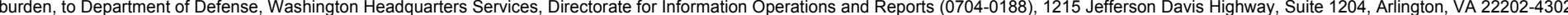

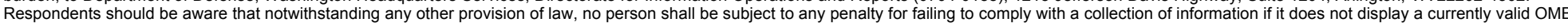
control number.

PLEASE DO NOT RETURN YOUR FORM TO THE ABOVE ADDRESS.

\section{REPORT DATE (DD-MM-YYYY) \\ 2. REPORT TYPE \\ 3. DATES COVERED (From - To)}

01-09-2007

\section{TITLE AND SUBTITLE}

Technical Memorandum

Reexamination of Ball-Race Conformity Effects on Ball Bearing Life

5a. CONTRACT NUMBER

5b. GRANT NUMBER

5c. PROGRAM ELEMENT NUMBER

\section{AUTHOR(S)}

Zaretsky, Erwin, V.; Poplawski, Joseph, V.; Root, Lawrence, E.

\section{5d. PROJECT NUMBER}

5e. TASK NUMBER

5f. WORK UNIT NUMBER

WBS 877868.02.07.03.01.01

8. PERFORMING ORGANIZATION REPORT NUMBER

E-15118-2

National Aeronautics and Space Administration

John H. Glenn Research Center at Lewis Field

Cleveland, Ohio 44135-3191

\section{SPONSORING/MONITORING AGENCY NAME(S) AND ADDRESS(ES)}

National Aeronautics and Space Administration

Washington, DC 20546-0001

\section{SPONSORING/MONITORS ACRONYM(S) \\ NASA \\ 11. SPONSORING/MONITORING REPORT NUMBER \\ NASA/TM-2007-213635}

\section{DISTRIBUTION/AVAILABILITY STATEMENT}

Unclassified-Unlimited

Subject Category: 37

Available electronically at http://gltrs.grc.nasa.gov

This publication is available from the NASA Center for AeroSpace Information, 301-621-0390

\section{SUPPLEMENTARY NOTES}

Submitted to the journal of STLE Transactions.

\section{ABSTRACT}

The analysis in this report considers the life of the ball set as well as the respective lives of the races to reassess the effect of ball-race conformity on ball bearing life. The related changes in ball bearing life are incorporated in life factors that can be used to modify the bearing predicted life using the Lundberg-Palmgren equations and the ANSI/ABMA and ISO Standards. Two simple algebraic relationships were established to calculate life factors $L F_{c}$ to determine the effect of inner- and outer-race conformity combinations on bearing $L_{10}$ life for deepgroove and angular-contact ball bearings, respectively. Depending on the bearing type and series as well as conformity combinations, the calculated life for deep-groove ball bearings can be over 40 percent less than that calculated by the Lundberg-Palmgren equations. For angular-contact ball bearings, the life can vary between +16 and -39 percent from that calculated by the Lundberg-Palmgren equations Comparing the two ball bearing types, the life factors $L F_{c}$ for the deep-groove bearings can be as much as 40 percent lower than that for angular-contact ball bearings.

\section{SUBJECT TERMS}

Probabilistic life prediction; Rolling-element bearings; Bearing life prediction; Weibull analysis

\section{SECURITY CLASSIFICATION OF:}

a. REPORT

$\mathrm{U}$

\section{b. ABSTRACT} $\mathrm{U}$

\section{LIMITATION OF} ABSTRACT

UU

18. NUMBER
OF
PAGES
31

31 19a. NAME OF RESPONSIBLE PERSON

Erwin V. Zaretsky

19b. TELEPHONE NUMBER (include area code) 216-433-3241 

